$\begin{array}{cc}\text { Tür Coğrafya Dergisi } & \text { Turkish Geographical Review } \\ \text { Basilı ISSN 1302-5856 } & \text { www.tcd.org.tr }\end{array}$

\title{
COVID-19 Pandemi sürecinde mevsimlik gezici tarım işçiliği ve çalışma koşulları üzerine bir inceleme: Beylikova (Eskişehir) örneği
}

\section{An examination on seasonal traveller agricultural labour and working conditions in the COVID-19 Pandemic process: A case study of Beylikova (Eskişehir)}

\author{
Sedat Benek ${ }^{\mathrm{a}}$ (D) Recep Baydemir *b (D) Selim Bozdoğan ${ }^{\mathrm{c}}$ \\ ${ }^{a}$ Harran Üniversitesi, Fen-Edebiyat Fakültesi, Coğrafya Bölümü, Şanlıurfa, Türkiye. \\ ${ }^{b}$ Harran Üniversitesi, Sosyal Bilimler Enstitüsü, Coğrafya Anabilim Dalı, Şanlıurfa, Türkiye. \\ c Harran Üniversitesi, Sosyal Bilimler Enstitüsü, Coğrafya Anabilim Dalı, Şanlıurfa, Türkiye. \\ ORCID: S.B. 0000-0002-5221-9683; R.B. 0000-0002-6263-5242; S.B. 0000-0001-8852-8974
}

\section{BÍLGI / INFO}

Geliş/Received: 24.10.2020

Kabul/Accepted: 01.12.2020

\section{Anahtar Kelimeler:}

COVID-19 Pandemisi

Mevsimlik gezici tarım işçiliği

Çalışma koşulları

Nöbetleşe yoksulluk

Beylikova (Eskişehir)

\section{Keywords:}

COVID-19 Pandemic

Seasonal travelling agricultural labourer

Conditions of working

Alternately poverty

Beylikova (Eskişehir)

*Sorumlu yazar/Corresponding author:

(R. Baydemir)

recepbaydemir@outlook.com

DOI: $10.17211 /$ tcd. 815947

\section{Atf/Citation}

Benek, S., Baydemir, R., \& Bozdoğan, S. (2020). COVID-19 Pandemi sürecinde mevsimlik gezici tarım işçiliği ve çalışma koşulları üzerine bir inceleme: Beylikova (Eskişehir) örneği. Türk Coğrafya Dergisi, 76, 75-94.

DOI: $10.17211 /$ tcd.815947.

\section{ÖZ / ABSTRACT}

Tüm dünyayı etkisi altına alan Covid-19 Pandemisi, gelişmiş ülkeler de dahil olmak üzere, tüm ülkeleri ekonomik ve sosyal olarak kasıp kavurmaya devam etmektedir. Bu anlamda, çocuk işçiler ve mevsimlik gezici tarım işçileri gibi toplumun en kırılgan grupları, bu süreçten nasibini en çok alanlar arasında yer almayı sürdürmektedir. Söz konusu sebeple bu araştırma, Şanlıurfa ilinin Eyyübiye ilçesinden Eskişehir ilinin Beylikova ilçesine çalışmak üzere her yıl düzenli olarak giden mevsimlik gezici tarım işçilerinin pandemi sürecindeki çalışma koşullarını irdelemeyi amaçlamaktadır. Temelde alan araştırmasına dayanan bu çalışma, öncelikle, pandemi sürecinde eşitsizliklerin ve yoksullukların fazlasıyla yaşandığı en kırılgan yaşam formlarından birine sahip olan mevsimlik gezici tarım işçiliğini, "yoksulluk kültürü", "yoksulluk kısır döngüsü", "nöbetleşe yoksulluk" gibi farklı kavram ve kuramlar bağlamında inceleyerek bir çerçeve oluşturmaktadır. Bu anlamda nitel araştırma yönteminin kullanıldığı bu incelemede, Beylikova ilçesinde çalışan mevsimlik gezici tarım işçi aileleri (2'si 'çavuş/elçi' ve 13'ü de 'işçi/amele' olmak üzere toplam 15 kişi) ile 16-20 Temmuz 2020 tarihleri arasında yapılan 'yüz yüze derinlemesine görüşme' ve 'yerinde gözlem ve inceleme' gibi araştırma tekniklerinden elde edilen verilerden hareket edilmektedir. Sonuç itibariyle bu araştırmada, Covid-19 Pandemi süreciyle birlikte mevsimlik gezici tarım işçilerinin ulaşım masraflarının ikiye katlandığı; çadırlarda kalan kişi sayısının azaltılmasından dolayı alınması gereken çadır sayısının artırıldı̆̆ı; buna rağmen bir çadırda yaklaşık 6-7 kişinin kaldığı; kadınların erkeklere oranla çok daha fazla çalışmak zorunda kaldıkları; en önemlisi de, mevsimlik gezici tarım işçilerinin, başta işverenler olmak üzere, gittikleri yerlerde çeşitli kesimlerce "insani onurları" aşağılanacak düzeyde sosyal dışlanmaya maruz kaldıkları saptanmıştır. Ayrıca, mevsimlik gezici tarım işçilerinin gittikleri alanlarda çok uzun süre güneşe maruz kaldıkları, sıtma, tansiyon, kalp hastalıkları gibi çeşitli hastalıklara yakalandıkları; bazı yerlerde temiz suya erişemedikleri için, içtikleri su yüzünden birçok kişinin hastanelik oldukları da çarpıcı biçimde ortaya çıkmıştır.

Covid-19 Pandemic which is the impact all over the world, not just the most developed countries, every country suffering from the same impact as both economical and social. The most fragile side of society like child labour and seasonal agricultural labour who is the most affected side of this pandemic can be still progressing in these circumstances. By the reason of this research, in processing pandemic, seasonal traveller agricultural labour who are going for working regularly every year from the province of Şanlurfa to county Eyyubiye to Beylikova in Eskişehir, aim relating about the schedule of working conditions. Basically this research, as a branch of research, first of all, in process of the pandemic, seasonal traveller agricultural labour who is the one of the most fragile living form having into the inequal poverty eminently, its composing different Notion and chain of the theory like "poverty culture", "poverty of infertile circle", "alternately poverty". In this sense qualitative research method was used in this study, seasonal traveller agricultural labours' families who work in Beylikova (2 of them sergeant and 13 of them labourer about, a total of 15 people). Techniques, that made among the date of 16-20 July 2020, which were the purpose of gained conclusion from "face to face deeply interview", "on-site observing and examination". As a result, in this research, it was doubled of seasonal agricultural workers' expenses with covid-19 pandemic progress. Because of was decreased amount of person who stays in the tents, they need to buy more tents, although the amount of staying in the one tent 6-7 person, women have to work a range of men, the most important seasonal travelling agricultural workers foremost, by the employer, it has been determined, they exposed to social-press, places where their went to various regions by means humiliate the honours of they humanity. Also seasonal travelling agricultural workers, because they exposed to more sun and caught an infection their places where they go, such as malaria, tension, heart diseases various illness. It is a striking fact that for they could not access to clean water, because of this unclean water many people had gone to the hospital in some places. 


\section{Extended Abstract}

\section{Introduction}

Since 1950s years has started to immigration from prairi to city, first of all in the agriculture mechanization depending other reasons heavy landless or existing land because of family's cannot to ensure their livelihood in the Turkey. From the point of view of the Southeastern Anatolia Region, It has been observed that those who migrated from rural to urban for these and similar reasons either went to large and medium-sized cities such as Gaziantep, Şanlıur$\mathrm{fa}$, Diyarbakır within the region or to large cities with more job opportunities in western regions such as Ankara, Adana, Bursa, Kocaeli, Istanbul, and Izmir. In the Southeastern Anatolia Region, it has been only choices, going on work, people whose come middle and big scaled cities, because of couldn't have developed to industrial sectoror cannot become offering an other sector also, by accomodation in the perimeterts of cities for years, the best known and it doesn't need to much qualification which agriculturel activities.

As a result of this, great numbers of family, have obliged to go to where finding agriculturel job opportunity as seasonal travelling agriculture employee for ensure their livelihood. It is divided into three types, work which in their jobs, in the agriculturel employee free family employee, tropical agriculturel employee, and seasonal travelling agriculture employee. Seasonal travelling agriculture employee generally are go to becoming work opportunity where with their all family's members and their all ecuipments, provisions for working. Thus, they are stoped over place's where their go to by employer. They are trying to hold on places given for their accomodation with their opportunities so. To trying to accomodation in this unhealthy conditions seasonal travelling employe families and also children about all family work to together and this families are affected because of sun tan, shortly from bad work and life conditions.

In addition to all these, a new epidemic virus, the first of which was defined as Covid-19, emerged in Wuhan Province, China, on 17 November 2019, and this epidemic later spread almost all over the world. Covid-19 has affected and also it is going on affect to 3,3 billions work force, with its in all the world creating big economic upside-down and working times affects. It has been underlined, in April month 2020, published by ILO, Covid-19 and Working World named in report, emigre employee have stayed more defendless towards Covid-19 Pandemia and in this situation, employee's both reach to their working placesand turn back to their family's opportunities, it will be limited. Also it has been evaluated of seasonal travelling employee are in the "most risk group".

Covid-19 Pandemia, by taking hold of all the world as economic and social while it affect to, even the most developed countries, also the most fragile of society group lik ese- asonal travelling agriculture employee taked their destiny, also between in the taking their destiny and goning on take from this negative process. It is came about, in addition of pandemia, relating to seasonal agricultural labouring that enacte to publicmadate (89780865-153, E -6202 numbered circular), in this circumstances, as a justification for seasonal agricultural laboures employment now that, the agricultural production not to stop by and deduction, provide to required man power and agricultural productions providing sustainable taking a part in it. In the same circular, "by saying; will have been taked to preocutions for nomad sandapiarists, their going in places, as it is possible they shouldn't contact to local community", as well as, as sacrifice to "nomads" or local community, in the other hand is caused to, "shouldn't contact need to as groups" by affect to their alienated.

It has been started to showed up seasonal travelling labourer who unvisibles of society and doesn't important working of conditions are not much topic of debate, with Covid-19 Pandemic temporarily visibility their seasonal travelling agricultural families and workers's working which children in this sector has been deserted to being talked about this process, by abandoning head to head with their destinity. As a fragile group, seasonal travelling agricultural workers has got stuck in between poverty and virus Seasonal travelling agricultural workers, in the process of pandemia situation, topic of this work, it is constitue that prepared by Grand National Assembly of Turkey searching comitte, in the 2015 year rapord, which it wasde scribed; himself/herself or another person, working in the about agricultural planting, growing disinfestation like reaping, working any in the process of agricultural producing, gainful/perdiem of some payment with engagement or without engagement, becoming country's citizen constantly or travelling seasonal working person. Accordingly, this work, first of all it is aimed that by composing a perpective topic of seasonal travelling agricultural working, such as; "poverty-culture", "poverty vicious circle", and "rotation poverty" dealing concepts and theory in the context of.

\section{Data and Method}

This study tried to prove to a sample, about seasonal travelling workers's life a working, searching was made about, 16-20 July 2020 dated, seasonal travelling agricultural workers where placed Eskişehir's city in Beylikova town. In scope of research at least, it has been made for 15 year, a mision researching regularly coming from Şanlıurfa to hear worker families's generally situations and prove in pandemic process, working and life conditions, in Beylikova. According to, it was travelled to, tente of seasonal travelling agricultural workers, in the their hand wasfound in observation and examination. After then along three day, was made face to face throughly examinations in the area with seasonal travelling agricultural workers. As such was made face to face throughly meetings between 16-20 July 2020 
dated, as two of them sergeantand 13 of them worker, total with 15 persons, it was made focus group meetings. Going talked about this persons's family's members finding here tente. It was went on in the last day of searching, both from field and from tente areas. In this mean, by taking photo sand was taked noted. By getting information, on the one hand, making searching of area and throughly meeting results in the procees of pandemia, finding in the field workers's healthy, transportation, accomodation nutrition and working conditions on the other hand, it has been tried to a analyze, a working related to agricultural workers's working conditions, reflected to pres news and related to this range made academic workings by compiling.

\section{Results and Discussion}

As as result of; this searching, process in pandemia seasonal travelling agricultural workers's their transportations's expenses; because of decreased of in the tente person; increasing of buy need to amonunt of tents, in this process towards to Covid-19 don't have healty a measuring fever, even it was made, it was only symbolic, age of working was lowered as far as 10-12 ages, daily; was worked 1112 hour with low wage and without insurance, by staying 6-7 person in the tent; hardness accesing to clean water and soap; women are worked more than men, also women have to do more shift, because of working in the field and also they have to do in the celaning works and dinner in the tents; almostly, women and young girls haveto work for 15 hours daily. It has been determined seasonal travelling agricultural workers's, foremost given by employer; in existing humanistic pride humiliate, they expoured to social oppression where they go for working. It has been observed that more beter seasonal agricultural workers having "labour life and working conditions" by adding pandemia conditions.

Seasonal agricultural workers have been obseved to worsen with the addition of pandemic conditions to poor living conditions. In addition, it is stringly revealed that seasonal migrant farm workers suffer from malaria, blood pressure, heart disease and various illnesses due to the use of intensive pharmaceutical fertilizers in areas where they go in the sun for a long time, they can't access clean drinking water and drink unclean water, therefore, it has been revealed that many people are hospitalized.

\section{Giriş}

"Yoksulluk virüsten daha öldürücüdür. (...) Bizi virüs değil; içinde bulunduğumuz bu kötü koşullar, açlık ve yoksulluk öldürüyor" (Ahmet, erkek, 55 yaşında, görüşme tarihi: 17.07.2020).

"Biz bayramımızı hiç Urfa'da geçirmedik. Hep burada [Beylikova'da] geçirdik. O yüzden Urfa'da bayram nasıl oluyor bilmiyorum. (...) Her bayram kendime söylüyorum, 'keşke bu bayram Urfa'da olsam'. Diyorum ki, 'gelecek sene bu bayramda Urfa'da olacağım'. Öyle umut ediyorum hep. Küçüklüğümden beridir hep bunu hayal ettim. Ama şimdiye kadar hiçbir bayramda Urfa'da kalamadım. Hep başka bir şehirde ve çadırlarda bayramı geçirdim" (Zehra, mevsimlik gezici tarım işlerinde çalışan bir çocuk işçi, 14 yaşında, görüşme tarihi: 17.07.2020).

Türkiye'de 1950 'li yıllardan itibaren başta tarımda makineleşme ve diğer nedenlere bağlı olarak ağırlıklı topraksız ya da var olan toprağın ailenin geçimini sağlayamamasından dolayı kırdan kentte göçler başlamıştır (Erkan, 2010: 98-102; Benek \& Ökten, 2011: 657). GAP Bölgesi ${ }^{1}$ (Benek, 2009: 47-52) açısından bakıldığında, bu ve benzeri gerekçelerle kırdan kente göç edenlerin ya bölge içindeki Gaziantep, Şanlıurfa, Diyarbakır gibi büyük ve orta ölçekli kentlere ya da Ankara, Adana, Bursa, Kocaeli, İstanbul, İzmir gibi batıdaki daha fazla iş olanağı bulunan büyük kentlere gittikleri görülmüştür. GAP Bölgesi'ndeki orta ve büyük ölçekli kentlere gelen insanlar, sanayi sektörü geliş(e)mediğinden veya istihdam olanağı sunan başka alt sektörler de ol(a)madığından kentlerin çeperlerinde ikamet edip yıllardır en iyi bildikleri ve çok da nitelik gerektirmeyen tarımsal faaliyetlerde çalışmaya devam etmek nerdeyse tek seçenekleri olmuştur.

İşte bunun sonucu olarak birçok aile, geçimini sağlamak için daha fazla tarımsal iş olanağı bulunan yerlere mevsimlik gezici tarım işçisi olarak gitmek zorunda kalmaktadır. Mevsimlik gezici tarım işçileri genellikle tüm aile fertleri, erzakları, araç gereçleriyle birlikte çalışmak üzere iş olanağı olan yerlere gitmektedirler. Bu sebeple, gittikleri yerlerin işverenleri tarafindan gösterilen yerlerde konaklamaktadırlar. Konaklamaları için kendilerine verilen yerlerde kendi olanakları ile orada barınmaya ve böylelikle hayata tutunmaya çalışmaktadırlar. Özellikle de gittikleri yerlerde sağlıklı olmayan kötü koşullarda barınmak zorunda kalan mevsimlik gezici tarım işçileri, eğitim çağındaki çocuklar da dahil olmak üzere bütün aile birlikte çaış̧makta (Fotoğraf 1) ve bu aileler, tarım ilaçlarından, güneş yanıklarından, kısacası kötü çalışma ve yaşam koşullarından olumsuz etkilenmektedir (Benek \& Ökten, 2011: 657). Ayrıca mevsimlik gezici tarım işçileri, sahip oldukları kötü yaşam koşulları sebebiyle gittikleri yerlerde sosyal dışlanmalara da maruz kalmaktadırlar.

\footnotetext{
1 Bu çalışmada, "Güneydoğu Anadolu Bölgesi" yerine "GAP Bölgesi” ifadesi kullanılacaktır. Sebebi ise şöyle açıklanabilir: "GAP Bölgesi sınırları, Güneydoğu Anadolu Bölgesi sınırlarıyla örtüşmemektedir. Eğer GAP Bölgesi'ni sınırları, Güneydoğu Anadolu Bölgesinnin bilimsel anlamdaki coğrafi sınırlarıyla uyumlu olarak çizilmiş olsaydı: Akdeniz Bölgesi'nde Antakya-Kahramanmaraş Grabeni içinde yer alan Gaziantep ilinin İslahiye ve Nurdağı; Doğu Anadolu Bölgesi'nde kalan Adıyaman ilinin Çelikhan, Sincik ve Gerger; Diyarbakır ilinin Çüngüss, Lice ve Kulp; Batman ilinin Sason; Siirt ilinin Şirvan, Pervari ve Eruh; Şırnak ilinin de Merkez, Uludere ve Beytülşebap ilçelerinin GAP Bölgesi içinde yer almaması gerekirdi. GAP projesi, il bütünlüklerini bozmamak amacıyla söz konusu illeri bütün olarak GAP Bölgesi bünyesi içine almıştır. Dolayısıyla, biz de, bu çalıșmada, GAP Bölgesi'nin kapsam alanı bilimsel bir coğrafi bölgeyi teşkil etmemesine rağmen, GAP Bölgesi ifadesini kullanacağız. Bunun nedeni ise, bölgedeki yatırımların koordinasyonunu üstlenmiş olan GAP Bölge Kalkınma idaresi olmak üzere tüm kamu kurum/kuruluşlarınca bölgeye ilişkin derledikleri verilerin bu doğrultuda yapılmış olmasıdır. Buna göre, GAP Bölgesi'nde Adıyaman, Batman, Diyarbakır, Gaziantep, Kilis, Mardin, Siirt, Şanlıurfa ve Şırnak illeri bulunmaktadır. Bu 9 ili kapsayan GAP Bölgesi, 75,410 km²lik bir alan kaplamaktadır" (Benek, 2009: 48-49). GAP Bölgesi'nin lokasyonu için Şekil 1'e bakınız.
} 


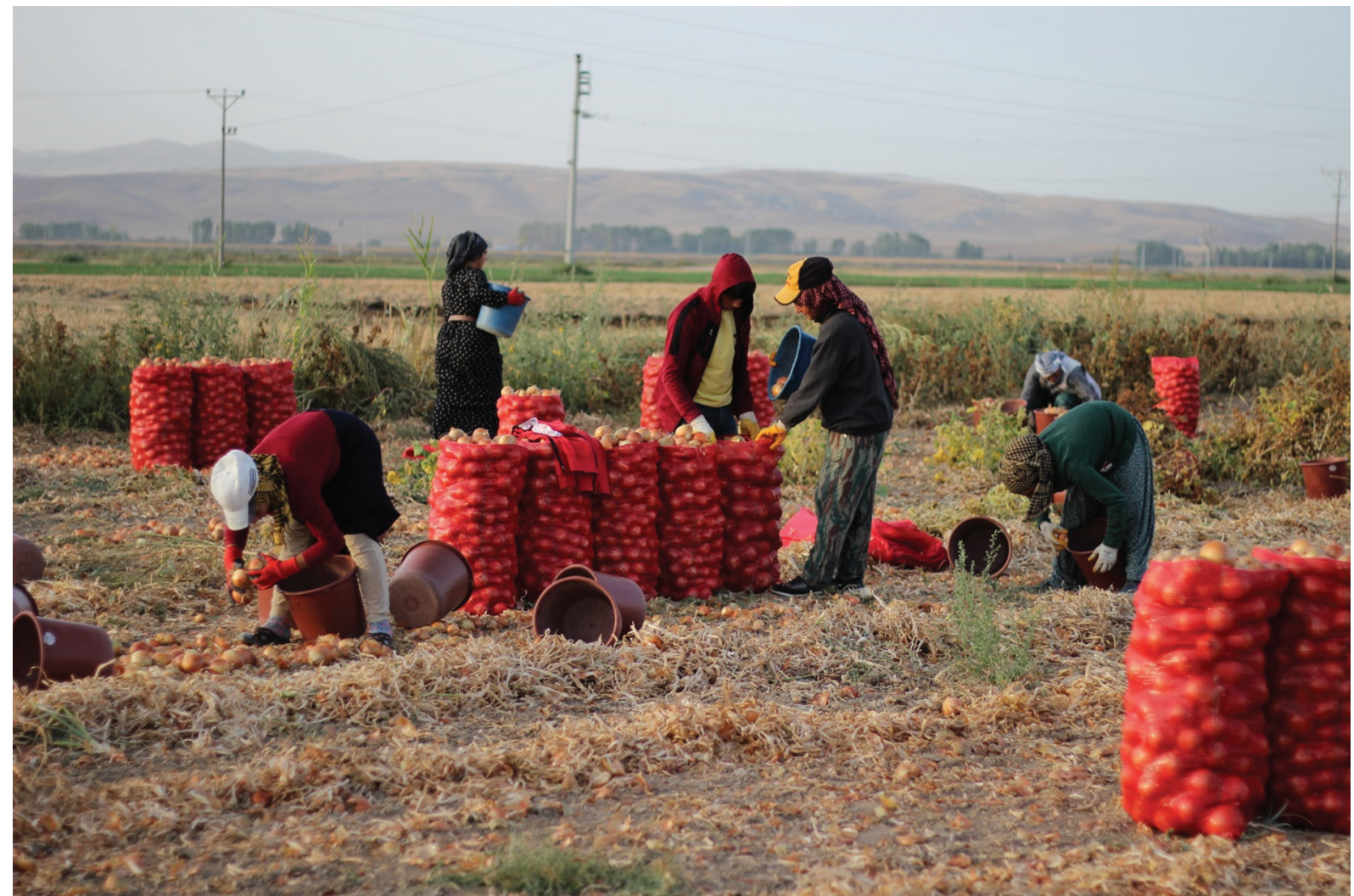

Fotoğraf 1. Covid-19 Pandemi sürecinde eğitim çağındaki çocuklar aileleriyle birlikte Beylikova'da mevsimlik gezici tarım işlerinde çalışıyor Photo 1. Children of school age working with their families in seasonal agricultural works in Beylikova, during the Covid-19 Pandemic Kaynak: Bilal Çiftçi, Temmuz, 2020.

Bütün bunlara ek olarak, ilki Çin'in Vuhan Eyaleti'nde 17 Kasım 2019 tarihinde Covid-19 olarak tanımlanan yeni bir salgın virüsü ortaya çıkmış ve bu salgın daha sonra neredeyse tüm dünyaya yayılmıştır. "Yarattı̆ı büyük bir ekonomik altüst oluş ve çalışma süreleri üzerindeki etkileri ile, COVID-19 krizi, dünyada 3,3 milyarlık işgücünü etkilemektedir" (ILO, 2020a: 4). ILO’nun 18 Mart 2020'de yayımladığı Covid-19 ve Çalışma Yaşamı: Etkiler ve Yanıtlar adlı raporda, göçmen işçilerin Covid-19 salgının etkilerine karşı çok daha savunmasız kaldıklarının ve bu durumun da işçilerin hem çalışma yerlerine erişme hem de ailelerine geri dönme imkânlarını kısıtlayacağının altı çizilmiştir (ILO, 2020b: 6). Ayrıca, ILO tarafindan 7 Nisan 2020'de yayımlanan bir diğer raporda ise, tarım sektöründe çalışanlar, Covid-19 sürecinde "en büyük risk altındaki sektörler" grubu içinde oldukları değerlendirilmiştir (ILO, 2020a: 4).

Covid-19 Pandemisi, gelişmiş ülkeler dahil tüm ülkeleri pek çok açıdan etkilerken, toplumun en kırılgan gruplarından birisi olan mevsimlik gezici tarım işçileri bu olumsuz süreçten en çok etkilenen gruplar arasında yer almış ve almaya devam etmektedir. Pandemi şartlarında mevsimlik gezici tarım işçiliğine ilişkin İçişleri Bakanlığı tarafindan 3 Nisan 2020'de çıkarılan genelgede, bu süreçte mevsimlik gezici tarım işçilerinin çalıştırılma gerekçesi olarak "[t]arımsal üretimin kesintiye uğramaması için gerek duyulan insan gücünün sağlanması" ve "[t]arımsal üretimin sürdürülebilirliğinin sağlanabilmesi" yer almaktadır. Aynı genelgede, göçerler ve arıcıların gittikleri yerlerde mümkün olduğunca yerel halk ile temas etmemeleri için gerekli önlemlerin alınacağı belirtilmektedir (İçişleri Bakanlığı, sayı: 89780865153.E.6202).

Daha önceden de "toplumun görünmeyenleri" olan ve çalışma koşulları çok da tartışma konusu yapılmayan mevsimlik gezici tarım işçilerinin görünürlükleri, Covid-19 Pandemisi ile birlikte geçici olarak ortaya çıkmaya başlamıştır. Mevsimlik gezici tarım işçi aileleri ve bu sektörde çalışan çocuk işçiler söz konusu süreçte adeta virüs ile baş başa bırakılarak kaderlerine terkedilmiştir. Kırılgan bir grup olarak mevsimlik gezici tarım işçileri bu süreçte 'yoksulluk' ile 'virüs' arasında sıkışıp kalmışlardır (Benek, 2020a; 2020b). Sözü edilen çerçeveden hareketle, bu çalışmanın konusunu, Türkiye Büyük Millet Meclisi Araştırma Komisyonu tarafindan 2015 yılında hazırlanan raporda, "kendisinin ya da başkasının tarım alanında ekim, yetiştirme, ilaçlama, hasat gibi tarımsal üretimin herhangi bir aşamasında çalışan, ücretli/ yevmiyeli veya ayni ödeme karşılığı, sözleşmeyle veya sözleşme olmaksızın, o ülkenin vatandaşı ya da göçmen olup sürekli ya da gezici mevsimlik çalışan kişi" olarak tanımladığı mevsimlik gezici tarım işçilerinin pandemi sürecindeki durumları oluşturmaktadır. Söz konusu sebeple bu çalışma, pandemi sürecinde hem mevsimlik gezici tarım işçilerinin durumlarına ilişkin genel bir tablo ortaya koymayı hem de mevsimlik gezici tarım işçilerinin çalışma koşullarını, "yoksulluk kültürü", "yoksulluk kısır döngüsü" ve "nöbetleşe yoksulluk" gibi kavram ve kuramlar bağlamında ele alarak bir inceleme yapmayı hedeflemektedir. 
Temelde alan araştırmasına dayanan bu çalışma, Beylikova ilçesinde çalışan mevsimlik gezici tarım işçi aileleri ile yapılan yüz yüze derinlemesine görüşmelerden elde edilen veriler ve saha çalışmasında yapılan gözlemlerden hareketle bir sonuca ulaşmaya çalışmaktadır. Bir taraftan yapılan alan araştırması ve derinlemesine görüşmeler sonucu, pandemi sürecinde tarlada bulunan işçilerin sağlık, ulaşım, beslenme, barınma ve çalışma koşulları ile ilgili bilgi elde edilirken diğer taraftan da mevsimlik gezici tarım işçilerinin çalışma koşulları ile ilgili basına yansıyan haberler ve bu alanla ilgili yapılmış akademik çalışmalar da derlenerek bir analiz yapılmaya çalışılmaktadır.

\subsection{Literatür Taraması}

Mevsimlik gezici tarım işçiliğinin, tarım ekonomisinden coğrafyaya, sosyolojiden kamu yönetimine, hatta hemşirelikten tıbba kadar pek çok disiplinin ilgi alanına girdiği görülmektedir. Pek çok disiplinden araştırmacı genel olarak mevsimlik tarım işçiliği ile ilgili çalışmalar yapmışlardır. Bu anlamda çok sayıda yüksek lisans tezinin (Bulut, 2013; Altın, 2014; Tabcu, 2015; Gira, 2017; Çakmak, 2018; Yiğit, 2018; Baş, 2019; Nuh, 2019; Yavuz, 2019; Aslan, 2020; Ata, 2020; Çayır, 2020; Şimşek, 2020;) ve doktora tezinin (Nazik, 1993; Çınar, 2012; Sevinç, 2015; Çarıkçı, 2016; Atış, 2019) yazıldığı görülmektedir. Bu alanda yazılmış makaleler de (Benek \& Ökten, 2011) bulunmakla birlikte, özellikle de Kalkınma Atölyesi'nin (Development Workshop, 2016a; 2016b; 2016c; 2018) çok sayıda yaptı̆̆ rapor çalışması da bulunmaktadır. Ayrıca Sidar Çınar'ın Öteki Proletarya: De-Proletarizasyon ve Mevsimlik Tarım işçileri isimli kitabı da mevsimlik tarım işçileri üzerine literatürde yazılmış en kapsamlı çalışmalardan birisi olarak göze çarpmaktadır. Burada bahsi geçen tüm çalışmalarda, mevsimlik gezici tarım işçilerinin pandemi öncesi durumu incelenmiştir.

Pandemi sürecinde mevsimlik gezici tarım işçiliği ile ilgili doğrudan yapılmış kapsamlı bir çalışma ise Development Workshop'un Virus or Poverty? Impact of Coronavirus Outbreak on Seasonal Migrant Agricultural Workers and their Children and on Crop Farming [Virüs mü Yoksulluk mu? Korona Virüs Salgınının Mevsimlik Gezici Tarım Iş̧̧ileri ve Onların Çocukları ile Bitkisel Üretime Olası Etkisi] isimli rapor çalışmasıdır (Development Workshop, 2020). Bu rapor çalışması, konuyu genel ve kapsayıcı biçimde ele alarak pandemi sürecinin mevsimlik gezici tarım işçilerine ve yapthkları üretime etkisini incelemiştir.

Covid-19 Pandemi sürecinde mevsimlik gezici tarım işçileri ile ilgili yapılmış uluslararası çalışmalara bakıldığında ise, evrensel düzeyde faaliyet gösteren çeşitli kurum ve örgütlerin rapor çalışmaları (FAO, 2020; ILO, 2020a; 2020b; 2020c; IOM, 2020; WTO, 2020) göze çarpmaktadır. Örneğin, Birleşmiş Milletler Gıda ve Tarım Örgütü (FAO), 2 Nisan 2020 tarihli Migrant Workers and the Covid-19 Pandemic isimli raporunda genel olarak Covid-19'un göçmen işçiler üzerindeki etkilerini belirtmektedir. Bu anlamda mevsimlik gezici tarım işçilerini de genel olarak göçmen işçiler içinde değerlendirmektedir. Güvenilir ve hijyen gıdaya kısıtlığın olduğunun belirtildiği raporda, göçmen işçilerin sağlık ve sosyal korumadan faydalanamadıklarının ve pandemi sürecinde virüse karşı savunmasız olduklarının alt çizilmektedir. Bir başka uluslararası örgüt olan Dünya Ticaret Örgütü (WTO) ise, 26 Ağustos 2020'de yayımladığı Covid-19 and Agriculture: A Story of Resilience isimli kısa bilgi raporunda, tarımda çalışanların yaşam ve çalışma formlarına etkisinden ziyade, Covid-19'un tarım ile olan ilişkisinde, tüm dünyadaki ticaret ürünleri arasında Covid-19 sürecinde diğer ticaret ürünlerinden daha dayanıklı olduğunu vurgulamıştrr. Ancak bu tarımsal ticaret ürünlerini bizzat üreten tarım işçilerinin bu süreçteki durumları raporda göz ardı edilmiştir (WTO, 2020). Benzer biçimde, Cortignani ve diğerlerine ait "Covid-19 and Labour in Agriculture: Economic and Productive Impacts in an Agricultural Area of the Mediterranean" isimli makalede, Covid-19'un mevsimlik gezici tarım işçilerinin çalışma ve yaşam koşullarına etkisinden ziyade, Covid-19'un İtalya'daki tarımsal işgücü piyasasına olan ekonomik ve tarımsal üretime etkisi incelenmiştir (Cortignagi vd., 2020). Bochtis ve diğerleri de "Agricultural Workforce Crisis in Light of the Covid-19 Pandemic" isimli makalelerinde, tarım işlerinde çalışanların çalışma koşullarına etkisi de dahil olmak üzere, Covid-19 bağlamında tarımsal işgücündeki krizleri incelemişlerdir.

Bu çalışmayı, burada bahsi geçen tüm çalışmalardan ayıran temel özelliği ise, bir taraftan pandemi sürecinde mevsimlik gezici tarım işçilerinin yaşam koşullarına odaklanması diğer taraftan ise, konuyu "yoksulluk kültürü", "yoksulluk kısır döngüsü", "nöbetleşe yoksulluk gibi" farklı kavram ve kuramlar bağlamında sorgulamasıdır.

\subsection{Araştırma Alanı ve Örneklem}

Bu araştırmanın evrenini Türkiye'nin Eskişehir ilinin Beylikova ilçesi olup, örneklemi de bu ilçede mevsimlik gezici tarım işlerinde çalışan ve rastgele seçilen 2'si çavuş/elçi ${ }^{2} 13^{\prime} u ̈$ de işçi/amele ${ }^{3}$ olmak üzere toplam 15 mevsimlik gezici tarım işçisidir. Çalışma alanı olan Beylikova, kuzeyde Alpu ve Mihalıççı, Güneyde ise Sivrihisar ve Mahmudiye ilçeleri ile çevrili olan bir ilçedir. Eskişehir iline bağlı bir ilçe olan Beylikova, Eskişehir il merkezinin doğusunda yer alır. İlçenin nüfusu yaklaşık yedi bin civarıdır ve yüzölçümü 570 kilometre karedir (Şekil 1).

\footnotetext{
2 Çavuş/elçi, işçi ile işveren arasındaki ilişkileri yürüten kişidir. Bunun karşılığında da iş̧̧inin kazandığının yüzde \%10’unu komisyon olarak kendisinden alır. Ancak, işçi de işverenden parasını almaz. Çavuş alır ve işçiye verir. İşverenin ücreti ödememesi durumunda iş̧̧i kendi ücretini çavuştan alır. Çünkü ilk görüşmede çavuşu vekil olarak atarlar. Bu işi yapanlar bölgeden bölgeye yöreden yöreye "çavuş", "elçi”, "dayı", "beybaşı”, "ağa” gibi farklı biçimlerde isimlendirilir.

3 Mevsimlik gezici tarım işlerinde genelde gündelikçi veya günlük yevmiye ile çalışan kişiye bazı yörelerde "işçi” bazı yörelerde "amele" denmektedir.
} 


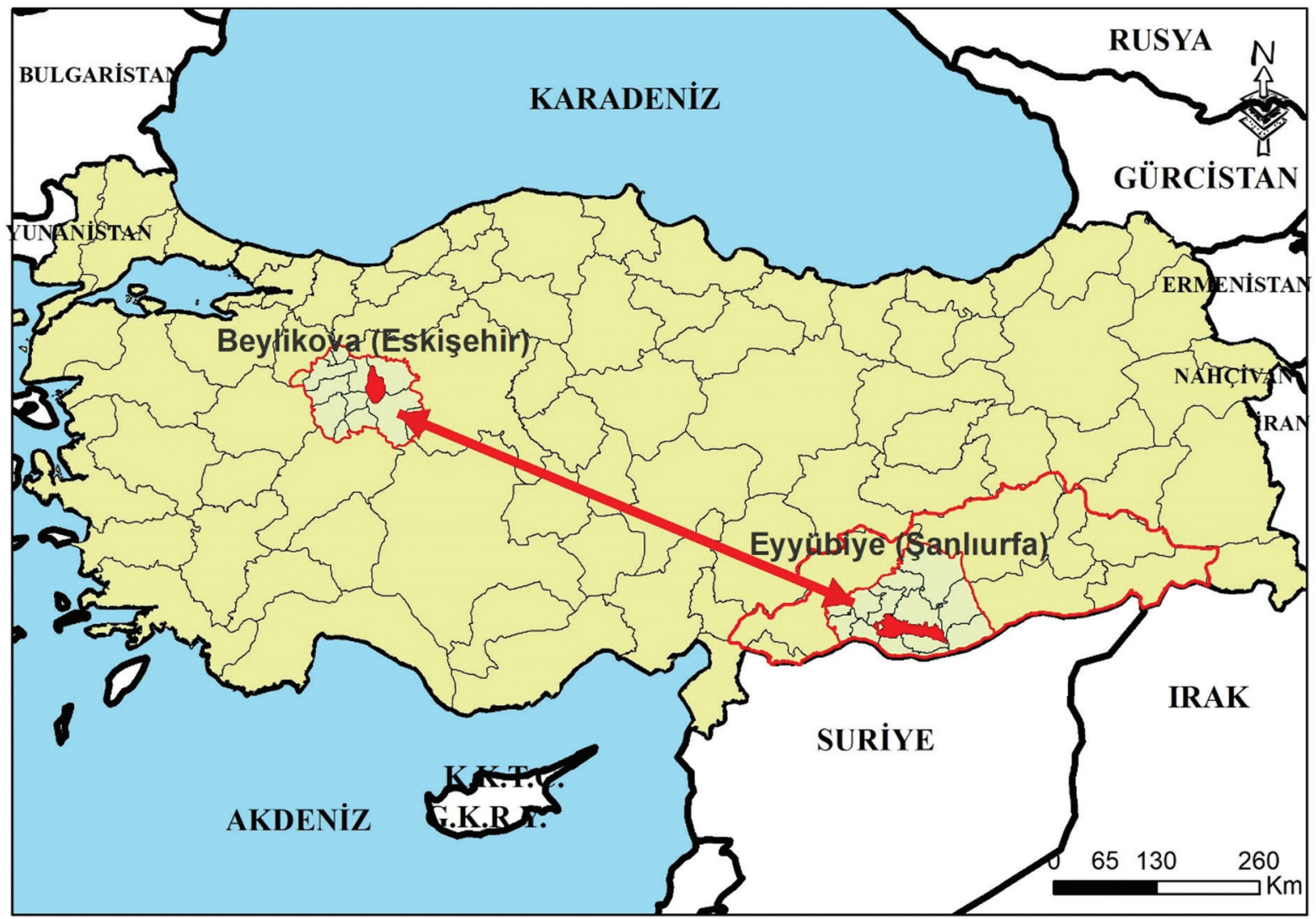

Şekil 1. Çalışma alanının lokasyonu

Figure 1. The location of study area

Başta Şanlıurfa olmak üzere, Güneydoğu ve Doğu Anadolu bölgelerindeki illerden her yıl yüzlerce insan aileleriyle birlikte, mevsimlik gezici tarım işlerinde (ekim, çapa, sulama ve toplayıcılık gibi) çalışmak için Beylikova (Eskişehir) ilçesine gelmektedir. Genelde 15 Nisan'da buraya gelen işçiler, 15 Kasım tarihine kadar burada kalırlar. Bu tarihten sonra ise, kazandığı bir miktar para ile geldiği yere geri dönerler. Bu araştırma kapsamında görüşülenlerin en az 15 yıldır buraya her yıl düzenli olarak gelip, 6-7 ay çalışıp sonra memleketine geri döndüğü saptanmıştır. Dolayısıyla aslında Beylikova ilçesi, mevsimlik gezici tarım işçiliği üzerine yapılacak bir çalışma için uygun bir çaıışma alanı niteliği taşımaktadır. Her yıl mevsimlik gezici tarım işçilerine ait yüzlerce çadırın kurulduğu (Fotoğraf 2) Beylikova ilçesi pandemi sürecinde mevsimlik geçici tarım işçilerinin yaşam koşullarının iyi okunabildiği Türkiye'deki başat yerler arasındadır.

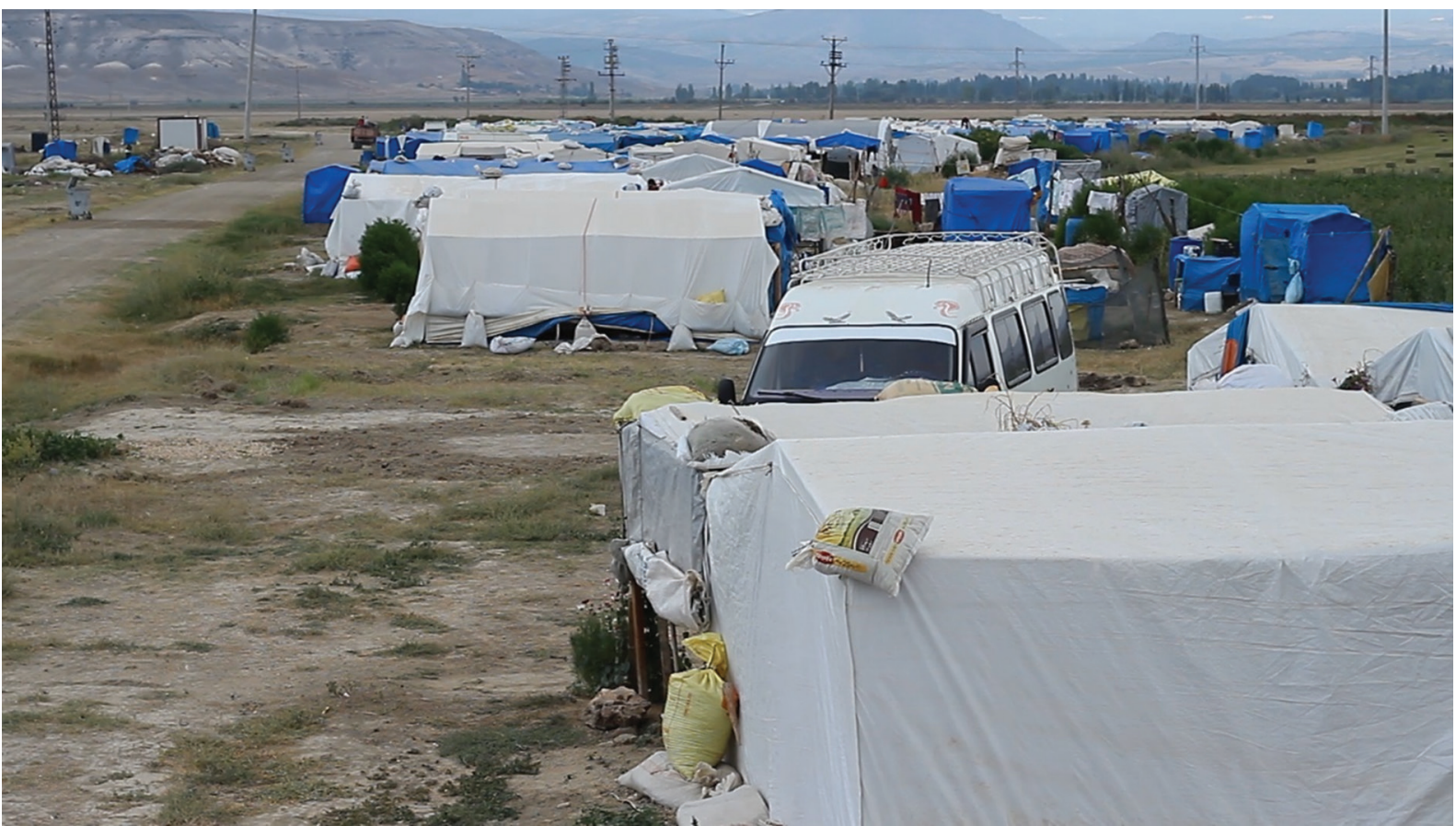

Fotoğraf 2. Beylikova'da mevsimlik gezici tarım işçi ailelerine ait yol kenarında kurulmuş çadırlar

Photo 2. Tents that roadside established belonging to seasonal agricultural worker families in Beylikova

Kaynak: Bilal Çiftçi, Temmuz, 2020. 


\subsection{Veri ve Yöntem}

Her yıl Şanlıurfa'dan Eskişehir'in Beylikova ilçesine gelen işçi ailelerinin genel durumları ve pandemi sürecindeki çalışma ve yaşam koşullarını ortaya koymak için Beylikova'da 16-20 Temmuz 2020 tarihleri arasında beş günlük bir alan araştırması yapılmıştır. Buna göre, araştırmanın ilk günü mevsimlik gezici tarım iş̧̧ilerinin çadırlarının bulunduğu mevkiler ziyaret edilmiş ve gözlemlerde bulunulmuştur. Daha sonra üç gün boyunca alanda mevsimlik gezici tarım işçileri ile yüz yüze derinlemesine görüşmeler yapılmıştır. Bu kapsamda 2'si 'elçi/ çavuş' ve 13'ü de 'işçi/amele' ve bunların da 7'si kadın, 8'i erkek olmak üzere toplam 15 kişi ile derinlemesine görüşmeler yapılmıştir. Söz konusu kişilerin aile fertlerinin tümünün toplandığı çadırlarda odak grup görüşmeleri de yapıımıştır. Araştırmanın son gününde ise hem tarladan hem de çadır alanlarından mevsimlik gezici işçilerin çalışma koşullarına ilişkin gözlemlerde ve incelemelerde bulunulmaya devam edilmiş, bu anlamda sahadan fotoğraflar çekilerek, notlar alınmıştır. Derinlemesine görüşmelerde katılımcıların hayat hikayelerini kısaca özetlemeleri istenmiştir. Bununla birlikte, mevsimlik tarım işçiliğine ilişkin algı ve yargıları, içinde bulundukları koşullarla baş etme stratejileri, pandemi sürecinde çalışma ve yaşam koşulları gibi çeşitli konulara ilişkin sorular sorulmuştur. Ancak her katılımcıya göre sorulan sorular da değişmiştir. Örneğin, çavuşa/elçiye sorulan sorular ile işçilere sorulan sorular değişebilmiştir. Kısacası, sorulan sorular katılımcının özelliklerine (yaş, cinsiyet, eğitim durumu, statüsü vs.) göre kısmen değişiklik göstermiştir.

Derinlemesine görüşmelerde, görüşme yapılanların ad ve soyad gibi kişisel bilgileri etik kurallar gereği gerçek kimliklerinin ifşa edilmemesi amacıyla, başka isimlerle şifrelenmesi tercih edilmiştir. Ancak derinlemesine görüşme yapılanlar hakkındaki diğer tüm detaylı bilgiler ise olduğu gibi aşağıdaki tabloda verilmiştir (Tablo 1).

Tablo 1. Görüşülenlerin genel profil özellikleri

Table 1. General profile characteristics of the interviewees

\begin{tabular}{|c|c|}
\hline 1 & $\begin{array}{l}\text { Ayşe, } 50 \text { yaşında, kadın, okur-yazar değil. Sekizi kadın, biri erkek olmak üzere dokuz çocuğu var. Bunlardan altısı evli. Evli olanların } \\
\text { tümü de erken yaşta mevsimlik işlerde çalışttklarından ve maddi imkânsızlıklardan dolayı ilkokulu bitirdikten sonra okuldan alın- } \\
\text { mış ve ortaokula devam edememişler. Ayşe, } 36 \text { yıldır mevsimlik gezici tarım işçisi olarak çalışıyor. }\end{array}$ \\
\hline 2 & $\begin{array}{l}\text { Ahmet, } 55 \text { yaşında, erkek, okur-yazar, Ayşe'nin eşi. } 38 \text { yıldan fazladır mevsimlik gezici tarım işlerinde çalışıyor. Evlendirdiği alt } \\
\text { çocuğundan birini, kendi rızası dışında başka biriyle evlendirdiği için pişman olduğunu ve vicdan azabı çektiğini söylemiştir. }\end{array}$ \\
\hline 3 & $\begin{array}{l}\text { Zehra, } 14 \text { yaşında, kadın, Ayşe ve Ahmet'in çocuğu. } 11 \text { yaşında iken ailesine yardım etmek için mevsimlik gezici tarım işlerinde } \\
\text { çalışmaya başlamış, } 3 \text { yıldır mevsimlik gezici tarım işçisi olarak ailesiyle birlikte çalışıyor. Şu an sekizinci sınıfa gidiyor. }\end{array}$ \\
\hline 4 & $\begin{array}{l}\text { Zeynep, } 16 \text { yaşında, kadın, Ayşe ve Ahmet’in çocuğu. O da kardeşi Zehra gibi } 11 \text { yaşında iken başlamış mevsimlik gezici tarım } \\
\text { işlerinde çalışmaya. } 5 \text { yıldır mevsimlik gezici tarım işçisi olarak ailesiyle birlikte çalışıyor. Şu an lise öğrencisi. }\end{array}$ \\
\hline 5 & $\begin{array}{l}\text { Mustafa, } 18 \text { yaşında, erkek. Lise son sınıf öğrencisi olan Mustafa, bir taraftan } 10 \text { yaşından beridir mevsimlik gezici tarım işlerinde } \\
\text { ailesine yardım ediyor diğer taraftan da eğitimini tamamlamaya çalışıyor. Mustafa aynı zamanda üniversite sınavına da hazırlan- } \\
\text { maya çalışıyor. }\end{array}$ \\
\hline 7 & $\begin{array}{l}\text { Süleyman, Çavuş, } 45 \text { yaşında, erkek, ilkokul mezunu. } 20 \text { yıldan fazladır mevsimlik gezici tarım işlerinde çalışıyor. } 16 \text { yıldır Şanlı- } \\
\text { urfa'dan Eskişehir Beylikova'ya mevsimlik gezici tarım işçi ailelerini götürüp getiriyor. Bu işçilerin yaptığı işlerden \%10 komisyon } \\
\text { alıyor. }\end{array}$ \\
\hline 8 & $\begin{array}{l}\text { Meryem, } 42 \text { yaşında, kadın, Süleyman'ın eşi. İlkokul terk. } 20 \text { yıldan fazladır mevsimlik gezici tarım işlerinde çalışıyor. } 16 \text { yıldır } \\
\text { düzenli olarak eşi ve ailesiyle birlikte Beylikova'ya gelip burada çalışıyor. }\end{array}$ \\
\hline 9 & $\begin{array}{l}\text { Ramazan, } 18 \text { yaşında, erkek, Süleyman'ın çocuğu. 7-8 yıldır ailesine yardım etmek için Mevsimlik gezici tarım işlerinde çalışıyor. } \\
\text { Lise öğrencisiyken okulu terk etmek zorunda kalmıştır. }\end{array}$ \\
\hline 10 & Eyyüp, 16 yaşında, erkek, Süleyman'ın oğlu. 5-6 yıldır mevsimlik gezici tarım işlerinde çalışıyor. Lise öğrencisidir. \\
\hline 11 & $\begin{array}{l}\text { Kıymet, } 15 \text { yaşında, kadın, ortaokul son sınıf öğrencisidir. Ayı zamanda lise sınavlarına da hazırlanmaya çalışıyor. 4-5 yıldır mev- } \\
\text { simlik gezici tarım işlerinde ailesine yardımcı olmak amacıyla çalışıyor. }\end{array}$ \\
\hline 12 & $\begin{array}{l}\text { Muharrem, } 60 \text { yaşında, erkek, okur-yazar. } 30 \text { yıldan fazladır mevsimlik gezici tarım işlerinde çalışıyor olsa da } 15 \text { yıldır Süleyman } \\
\text { Çavuş'la mevsimlik gezici tarım işlerinde çalışmak üzere eşi ve çocuklarıyla birlikte Beylikova'ya geliyor. }\end{array}$ \\
\hline 13 & $\begin{array}{l}\text { Hatice, } 56 \text { yaşında, kadın, okur-yazar değil, Muharrem'in eşi. } 30 \text { yıldan fazladır mevsimlik gezici tarım işlerinde çalışıyor olsa da } \\
15 \text { yıldır Süleyman Çavuş'la birlikte Beylikova'ya gelip burada çalışıyor. }\end{array}$ \\
\hline 14 & $\begin{array}{l}\text { Hatun, } 43 \text { yaşında, kadın, çavuş/elçi. İlkokul terk. } 25 \text { yıldan fazladır mevsimlik gezici tarım işlerinde çalışıyor. En az } 15 \text { yıldır çavuş- } \\
\text { luk/elçilik yapmaktadır. O da Süleyman Çavuş gibi işçilerden \% } 10 \text { komisyon alıyor. }\end{array}$ \\
\hline 15 & $\begin{array}{l}\text { İbrahim, } 22 \text { yaşında, erkek, Hatun'un oğlu. Ortaokulu bitirdikten sonra eğitimine devam edememiştir. En az } 10 \text { yıld } \\
\text { gezici tarım işlerinde çalışıyor. }\end{array}$ \\
\hline
\end{tabular}




\section{Tarihsel Olarak Mevsimlik Gezici Tarım İşçiliği}

Genel anlamda mevsimlik gezici tarım iş̧̧isi, başkasının tarım alanındaki herhangi bir işte çalışan ve tarımsal üretimin herhangi bir aşamasında ücretli-yevmiye ve ayni ödeme karşıIığında gezici olarak çalışan kişilerdir. Mevsimlik gezici tarım iş̧̧ileri, tarımsal hasat sezonuna göre ilden il'e bölgeden bölgeye gezen ve yılın yaklaşık sekiz ayı farklı bölgelerde tarımsal hasat işinde çalışanları ifade etmektedir. Bu işçilerin istihdam ve çalışma ilişkileri enformeldir ve kimi zaman sözleşmeli kimi zaman ise sözleşmesiz çalışmaktadırlar (Çınar \& Lordoğlu, 2011: 420). "Mevsimlik tarım işçilerinin ortak noktası, kendi tarım işletmelerinden yeterli geliri elde edememeleri, az topraklı veya topraksız aileler olmaları ve geçimlerini sağlayabilmek amacıyla daha fazla tarımsal iş imkânı olan yörelere mevsimlik olarak (gezici) şekilde göç etmeleridir" (Kılınç, 2018). Mevsimlik gezici tarım işçilerinin bu ortak özellikleri, tarihsel süreçte kırsal alanda meydana gelen toplumsal dönüşümlere bağlı olarak ortaya çıkmaktadır.

Türkiye'de 1950'li yıllardan itibaren kırsal alanda hem bir çözülme hem de yeniden bir yapılanmanın olduğu yeni bir dönüşüm yaşanmıştır. Dönüşüm tarımda makineleşme, toprak mülkiyetindeki yoğunlaşma, tarımsal üretim yapılmayan alanların hızla tarıma açılması gibi nedenlere bağlı olarak geleneksel üretim ve emek ilişkilerinde çözülmeler meydana gelmiştir (Çınar, 2014: 46; Arslan, 2018: 73). Özellikle tarımda makineleşmeyle birlikte tarıma açılan arazi sayısında önemli sıçramalar yaşanmıştır. Örneğin Şanlıurfa'da 1950-2019 yılları arasında makineleşmeye ile birlikte tarıma açılan arazi oranlarında sürekli artışlar olmuştur. Şanlıurfa'da 1927 yılında 61.000 hektarlık bir alanda tarımsal faaliyet yapılırken 1950 yılında 177.500 hektarlık alanda, 1960 yılında 508.000 hektarlık alanda, 1972 yılında 600.000 hektarlık alanda, 1981'de daha hızlı bir artışla 982.819 hektarlık bir alanda, 2002 yılında ise GAP'ın da etkisiyle bir milyonu aşarak 1.202.925 hektarlık bir alanda (Benek, 2005: 18), 2015 yılında 1.181.494 hektarlık bir alanda ve 2019 yılında ise 1.072 .925 hektarlık bir alanda tarımsal faaliyetler yürütülmüştür (TUiK, 2019). Bu anlamda 2019 yılı itibariyle Şanlıurfa ili sahip olduğu toplam tarımsal alanla Türkiye'de Konya ve Ankara illerinden sonra üçüncü sırada yer almaktadır. Ancak başta tarımda makineleşme olmak üzere çeşitli sebeplerle giderek artan tarım alanına karşılık Şanlıurfa ili Türkiye'de mevsimlik gezici tarım işlerinde çalışmak üzere dışa en çok göç veren başat illerden birisidir. ${ }^{4}$

Kırdan kente göç eden kişiler, ağırlık olarak topraksız ya da var olan toprağın ailenin geçimini sağlayamamasından muzdarip olan gruplardan oluşmaktadır. Bu bağlamda topraksız ailelerde meydana gelen bu azalış, kırsal alanda yaşayan 'topraksız ailelerin' büyük kısmının kentlere göç etmesinden kaynaklanmaktadır. Bir taraftan makineleşme ile birlikte iş̧̧i arzının azalması ve ortakçılık, yarıcılık gibi yöntemlerin ortadan kalkması, diğer taraftan da miras yoluyla toprakların bölünmesinin yarattı̆ı sonuçlardan dolayı özellikle de 1970'li yıllardan itibaren kırdan kente yoğun bir göç akını yaşanmıştır (Çınar, 2014: 46; Erkan, 2010, 98-99). Kırdan kente göçün en fazla yaşandığı bölgelerden biri de GAP Bölgesi'dir. GAP Bölgesi'ndeki orta ve büyük ölçekli kentlerde gerek sanayii sektörünün gelişmemesi gerekse istihdam olanağı sunan başka alt sektörlerin de olmaması, buralara göçle gelen insanların kentlerin çeperlerinde ikamet etmesine ve yıllardır en iyi bildikleri, çok da nitelik gerektirmeyen tarımsal faaliyetlerde çalışmaya zorlamıştır. Dolayısıyla Arslan'ın (2018: 69) da belirttiği gibi, mevsimlik gezici tarım işçileri tarım sektörünün nitelik gerektirmeyen işlerinde yoğunlaşmaktadırlar.

GAP Bölgesi'nde, 1980-1985 yılları arasında başlayan köyden kente göçler mevsimlik tarım işçilerinin oluşmasında ve çoğalmasında etkili olmuştur (Çınar, 2014). Bu yüzden Pelek'e göre Türkiye'de mevsimlik tarım işçiliğinde en çok Kürtler çaIışmaktadır (Pelek, 2011). Türkiye'de mevsimlik tarım işçiliğinin etnik temelli olması (Çingeneler, Gürcüler vs.) reel politik söylemlerin akışına göre dışlama ve ötekileştirme gibi olumsuz sonuçlar da doğurabilmektedir (Anonim, 4 Eylül 2020). Mevsimlik gezici tarım işçileri, dışlama ve ötekileştirmenin yanı sıra gündelik yaşam koşulları, sağlık durumları ve çocukIarın eğitimi gibi önemli sorunlarla da boğuşmaktadırlar. Bu sorunlar pandemi öncesinde de var olmakla birlikte pandemi sonrasında daha da 'ölümcül' bir hal almaya başlamıştır.

'Toplumun görünmeyenleri' olarak da kavramsallaştırılabilen 'mevsimlik gezici tarım işçileri' yaşam olanakları bakımından çalışma hukukunun dışında tutulmaktadır. Mevsimlik gezici tarım işçileri, başta barınma ve beslenme olmak üzere, ulaşım, eğitim ve sağlık gibi alanlarda yaşadıkları sorunlarla birlikte, haftanın yedi günü, günde on iki saate kadar sürebilen uzun çalışma süreleri, iş kazaları ve meslek hastalıklarına açık ağır çalışma koşullarına sahip olmaları, düşük ücretlerle çalışmaları ve yeterli yasal korumadan yoksun durumda olmaları (Öz \& Bulut, 2013: 94; Akalın, 2018) gibi pek çok handikapla karşı karşıya bulunmaktadırlar. Bu durum sağıık koşulları bakımından mevsimlik tarım işçilerini dezavantajlı yapmaktadır. Dolayısıyla Çınar'ın (2014: 34) da dikkat çektiği gibi, mevsimlik gezici tarım işçilerinin önemli bir bölümü yeşil kartlı olup, sağlık hizmetlerinden de yeşil kart aracılığıyla yararlanmakta ancak iş kazası, meslek hastalığı, emeklilik gibi sosyal güvenliğin diğer kollarından ise yararlanamamaktadırlar (Çınar, 2014: 34). Bu hukuksal boşluktan dolayı, hiçbir mevsimlik gezici tarım işçisi, meslek hastası tanısı alamamaktadır.

\footnotetext{
4 Türkiye'de mevsimlik gezici tarım işçiliğinin en yoğun olduğu illerin başında Şanlıurfa ilinin gelmesinin sebebi, bu ildeki “tarım alanlarının eşitsiz mülkiyet dağııımı”ndan kaynaklandığı söylenebilir. Nitekim Benek (2005) tarafindan yapılan bir çalışmada, Şanlıurfa ilinde 1981 yılında "topraksız köylülerin” oransal olarak en fazla olduğu üç ilçe sırasıyla \% 57,7 ile Siverek ilçesi,\% 49,4 ile merkez ilçeler (2012 büyükşehir yayası ile birlikte merkez ilçe Eyyubiye, Haliliye ve Karaköprü olmak üzere üçe ilçeye ayrılmış durumdadır) ve \% 47,6 ile Akçakale ilçeleridir. Aynı dönemde (1981) il genelindeki topraksız çiftçi oranı ise \%42,3’tür (Benek, 2005: 132). Bunlara az topraklı çiftçi aileler de eklenince Şanlıurfa ilinde bir hayli yüksek oranda mevsimlik gezici tarım işçiliğinin ortaya çıkması kaçınılmaz olmuştur (Benek, 2006: 77-78).
} 


\section{Covid-19 Pandemi Süreci ve Mevsimlik Gezici Tarım İşçiliğ}

Pandeminin sosyal ve ekonomik sürecini tartışan David Harvey, kişisel internet sitesindeki makalesinde, pandemi sürecini kapitalist ekonominin yeniden üretim süreci ile bunun işçilere olan etkilerini ele almaktadır. Harvey'e göre pandemi süreci ile birlikte 'yeni bir işçi sınıf' ortaya çıkmaktadır:

"Bu "yeni işçi sınıf" ön sırada yer alıyor, bu yüzden de ya yaptıkları iş gereği virüs bulaşmasında en fazla risk altındaki işgücü olmanın ya da virüs sebepli ekonomik kısıntı nedeniyle maddi bir kaynak sağlanmadan işten çıkarılmanın ağır faturasını ödüyor. Örneğin, kimin evde çalışabileceği ve kimin çalışamayacağı sorusu var. Bu, temas veya enfeksiyon durumunda kimin kendilerini (ücretli veya ücretsiz) izole edebileceği veya karantinaya alabileceği sorusu gibi, toplumsal bölünmeyi keskinleştiriyor" (Harvey, 2020).

Harvey'in ifade ettiği 'sosyal bölünmenin keskinleşeceği' düşüncesi, formel sektörde çalışan işçileri kapsamaktadır. Doğrudan emek gücü piyasasında faaliyet yürüten işçilerin de pandemi süreciyle birlikte önemli sorunlar yaşadığı ortadadır. Fakat 'mevsimlik gezici tarım işçileri' gibi enformel sektörde çalışanlar, pandemi sürecinde yoksulluk ve virüs arasında saIınım halindedir. Bu süreçte mevsimlik gezici tarım işçiliği ile ilgili çeşitli düzenlemeler getirilmiştir (Kamer, 2020).

Türkiye'de pandemi sürecinde, ilk aşamada 18-20 yaş arasında bulunan kamu çalışanları, özel sektörde çalıştğını belgeleyenler ve mevsimlik tarım işçileri sokağa çıkma yasağından muaf tutularak 'istisnai' bir konuma yerleştirilmiştir. İçişleri Bakanlığı'nın 3 Nisan'da iller İdaresi Genel Müdürlüğü üzerinden il valiliklerine gönderdiği 'Koronavirüs Tedbirleri/Mevsimlik Tarım İş̧ileri' konulu yazı, mevsimlik tarım işçilerinin çalışma biçimlerine dair süreçleri ele almaktadır. Mevsimlik tarım işçileri ile ilgili, İçişleri Bakanlığı tarafinda 81 il valiliğine gönderilen genelgenin birinci maddesi şöyledir (Yıldırım, 2020):

"Tarımsal üretimin kesintiye uğramaması için gerek duyulan insan gücünün her ilin kendi imkanları ile karşılanması esastır. İnsan gücü ihtiyacının il içerisinde karşılanamaması halinde öncelik civar iller olmak üzere diğer illerden de mevsimlik tarım işçileri ile tarımsal üretimin sürekliliği sağlanacaktır. Ancak bu durum ilgili Valiliklerin izin verme şartına bağlı olarak gerçekleşebilecektir. Bu şekilde iller arasında mevsimlik tarım işçisi hareketliliği olduğu takdirde iş̧̧ilerin yola çıktıkları iller "çıkış ili", tarımsal üretime katkı sağlayacağı il ise "varış ili" olarak tanımlanacaktır."

Yine ilgili yazının ikincisi maddesinde, "[t]arımsal üretimin sürdürülebilirliğinin sağlanabilmesi amacıyla her ilde valilerin başkanlığında ilgili kamu kurum ve kuruluşları ile meslek odaları temsilcilerinin katılımıyla (il Tarım ve Orman Müdürü, il Sağlık Müdürü, il AFAD Müdürü, il Göç Müdürü, kolluk temsilcileri, yerel yönetim temsilcileri, Ziraat Odası Başkanı vb.) bir komisyon kurulacaktır" (Yıldırım, 2020) denilerek, her ilde çeşitli kurumların katılımıyla bir komisyonun kurulacağı ve bu komisyonun mevsimlik tarım işçilerine yönelik tedbirleri ve denetimleri gerçekleştirebileceğine dikkat çekmektedir. 3 Nisan tarihli genelge, ilkin mevsimlik tarım işçi eksiklerinin belirlenmesi ve bu intiyaçların valiliklerce giderilebileceği; belirlenen mevsimlik gezici tarım işçilerinin sağlık kontrolüne tabi tutulduktan sonra "çıkış ili"nden "varış ili"ne gideceklerine vurgu yapmaktadır. Daha sonra 'çıkış ili' ile 'varış ili' valiliklerinin koordinasyonuyla transit taşıma işlemleri başlayacak ve sağlık kontrolleri yapılarak izolasyon süreçleriyle ilgili bilgilendirilecekleri ifade edilmektedir (İçişleri Bakanlığı, sayı: 89780865-153-E.6202):

“d) Çıkış ilinde/ilçesinden seyahat edecek kişiler ve taşıyacak şoför dahil, il/illçe Sağlık Müdürlüğü veya Toplum Sağlığı Merkezleri tarafindan sağlık kayıtlarından (HSYS vb.) evde tedavi izolasyonunda veya temaslı izolasyonunda bulunanların olup olmadığı kontrol edilecektir. Ayrıca iı/ illçe Sağlık Müdürlüğü veya Toplum Sağlığı Merkezlerinin uygun gördüğü sağlık tesisinde/alanında Sağıı Bakanlığı'nın yayımlamış olduğu "Ayaktan Başvuran Hastalar İçin Olası COVID19 Vaka Sorgulama Kılavuzu" kullanılarak sağIık kontrolünden geçirilecektir. Sorun tespit edilmeyenlere seyahat onayı Valiliklerin belirleyeceği belge üzerinden verilecektir. Ayrıca seyahat sırasında COVID19 hastalığından korunmak amaçlı uyulacak kuralları içeren bilgilendirme yapılacaktır."

Bu aşama sağlandıktan sonra, illerde kurulan komisyonun il/ İlçe Hıfzıssıhha Kurullarının görüşleri doğrultusunda sürecin yönetilmesine ve ilgili metinde belirtilen hususların eksiksiz bir biçimde uygulanmasına dikkat çekilmektedir. İlgili komisyonun almış olduğu tedbirler, mevsimlik tarım iş̧̧ilerine ekonomik açıdan büyük külfetlere neden olmaktadır. Seyahat sürecinde sosyal mesafenin getirilmesi, çadırlarda metrekare olarak yerleşimin sağlanması gibi durumlar mevsimlik tarım işçilerinin masraflarını iki katına çıkarmaktadır (Benek, 2020a; 2020b).

Bütün bunlarla birlikte, pandemi süreci öncesinde çok da görünür olmayan mevsimlik gezici tarım işçileri, pandemi sürecinde çıkarılan yasa ve genelgelerle birden görünür hale gelmeye başladılar. Çünkü pandemi sürecinde pek çok sektör çalışmaya ara vermek zorunda kalırken, neredeyse tüm şehirlerde belli günlerde sokağa çıkma yasakları sürerken mevsimlik geçici tarım işçileri çalışmak için başka illere gitmek üzere yollara düştüler. Ancak yola çıkmak için önce bulundukları ilin tarım il ve ilçe müdürlüklerinden izin almaları gerekti. Sadece Şanlıurfa'da bir hafta içerisinde 17 bin kişi seyahat izin belgesi almak için başvuruda bulundu (Anonim, 17 Nisan 2020). Türkiye'de mevsimlik tarım işçiliğinin en fazla olduğu illerin başında gelen Şanlıurfa'da pandemi sürecinde tarımda çalışmak üzere ilçe tarım müdürlükleri önünde oluşturulan kuyruklar ve sosyal mesafeye dikkat edilmemesi sebebiyle insanlar, hastalık kapma riskine rağmen, iç içe geçmiş ve izin almak için sıra beklemişlerdir. Bu durum ulusal basına da farklı şekillerde yansımıştır (Fotoğraf 3). 


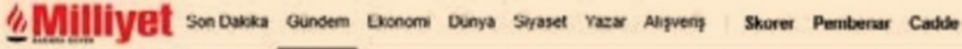

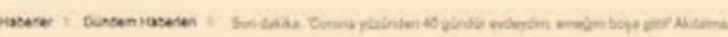 \\ Son dakika: 'Corona yüzünden $\mathbf{4 0}$ gündür evdeydim, emeğim boşa gitti!' Akılalmaz...}

Son dakika haberlere göre, Şanlıurfa'da mevsimlik tarım işçileri, corona virüs tedbirleri kapsamında şart koşulan seyahat izin belgesini almak için Ilçe Tarım Müdürlükleri önünde kuyruklar oluşturdu. Polis ekipleri, sosyal mesafeye aldırış etmeden yoğunluk oluşturanları uyardı.

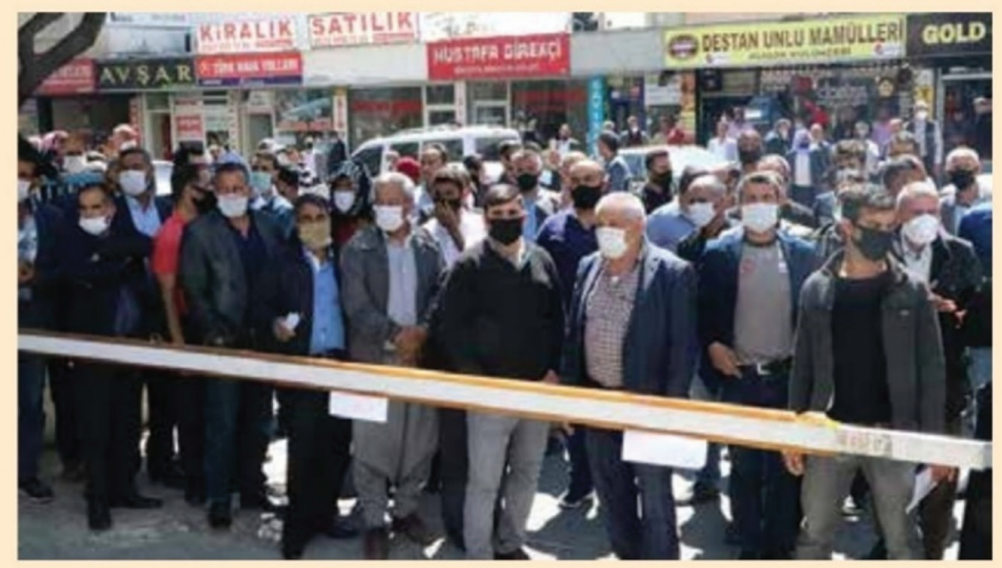

Şanlıurfa'da mevsimlik tarım işçisi olarak diğer şehirlere gitmek isteyenler Eyyübiye ve Haliliye Ilçe Tarım Müdürlüklerine gelerek seyahat izin belgesi için başvuruda bulundu.

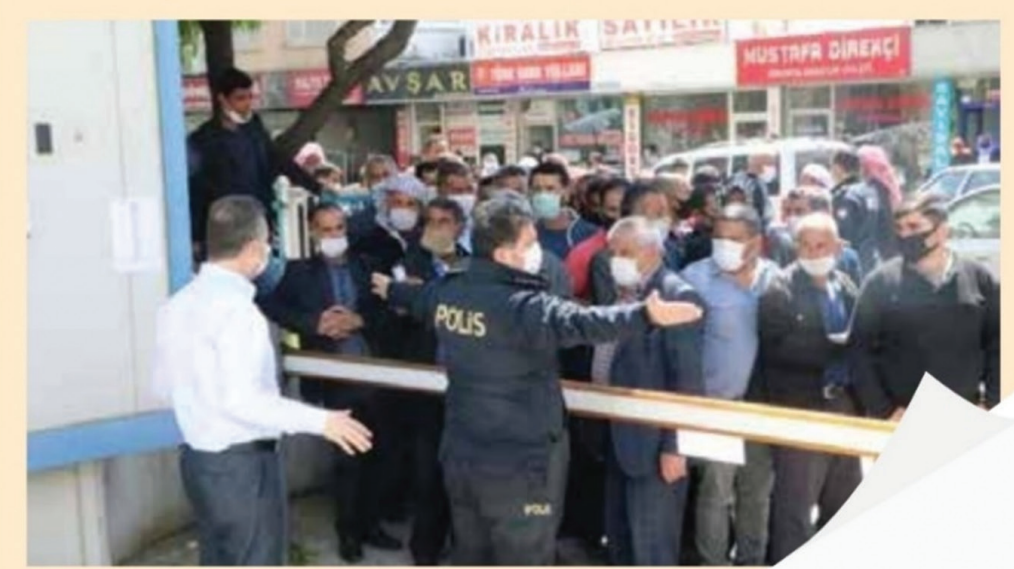

Fotoğraf 3. Covid-19 sürecinde izin almak için toplanan ve sıra bekleyen mevsimlik gezici tarım işçileriyle ilgili basına yansıyan bir haber Photo 3. A news in the press about seasonal agricultural workers who gathered and waiting in line to take permission in the Covid-19 process Kaynak: (Development Workshop, 2020, 70).

\section{4. "Yoksulluk Kültürü", "Yoksulluk Kısır Döngüsü" ve “Nöbet-} leşe Yoksulluk" Üçgeninde Mevsimlik Gezici Tarım İşçiliği

Bu çalışmanın amaçlarından biri de mevsimlik gezici tarım işçiliğinin "yoksulluk kültürü", "yoksulluk kısır döngüsü" ve "nöbetleşe yoksulluk" kavram ve kuramları bağlamında sorgulanmasıdır. Nitekim, çoğu kez mevsimlik gezici tarım işçiliğinden bahsedilirken yoksulluk (özellikle de yoksulluk kültürü) fenomeni sıklıkla dile getirilir. Ancak bu kavramlar arasındaki ilişkiler tam olarak ortaya konulmadığından çoğu kez yanlış anlaşılmalara sebep olunmaktadır. Mevsimlik gezici tarım işçiliğinin yoksulluk fenomeniyle yoğrulan bu kavramlarla olan ilişkisinin bilinebilmesi için öncelikle bu kavram ve kuramların ne olduğu veya bunların neyi çağrıştırdığının bilinmesi gereklidir.

Bu bağlamda mevsimlik gezici tarım iş̧̧iliğinden bahsedilirken sıklıkla dillendirilen bu kavramlardan ilki olan yoksulluk kültürü (culture of poverty) çoğunlukla Oscar Lewis ile bilinir ve onun tarafindan kavramlaştrılmıştr. Bu kavram, Lewis'in Porto Rikolular ve Meksikalılar üzerine yaptığı alan çalışmaları üzerinden şekillenmiştir. "Yoksulluk kültürü kavramının sadece Lewis'i popüler yapmakla kalmadığı, kavramın içerdiği popüler anlam ve nitelemelerle çoğu olumsuz özelliklerin atfedilmesiyle yoksullara karşı bakışı da şekillendirdiği, yoksullar ve yoksulluk üzerine yapılan tartş̧malardaki yoksulluk kültürü yaklaşımının kullanımından çıkarılabilir" (Özdoğan, 2010: 98). Özdoğan'ın da vurguladığı gibi, Türkiye'de "yoksulluk kültürü" üzerinde doğrudan yapılmış akademik çalışmaların pek de olmamasına karşın, bu kavram basın-yayın yoluyla kavramsallaştırılarak popüler bir hale gelmiştir. Onun bu popüler yönü, "yoksulların yoksulluklarından dolayı suçlanması" ve "bundan dolayı yoksullara dönük yapılan sosyal yardımların eleştirilmesinde yaygın olarak kullanılmasından" kaynaklanmaktadır. Bu sebeple de çoğu zaman bilimsel anlamlardan uzak biçimde 
kullanılmaktadır ve bu kavram üzerinden yapılan yakıştırmalarla yoksulların aldıkları sosyal yardımlar aracılığıyla "yoksulluk kültürü"ne alıştırıldıkları eleştirisi de sıklıkla yapılmaktadır (Özdoğan, 2010: 98).

Bununla birlikte, "yoksulluk kültürü" aynı zamanda, "[h]er şeyin sonucunun [önceden] belli olduğunu, çaba harcayarak ya da önceden harekete geçerek bu sonuçlardan kaçılamayacağını ve bu durumun sadece yaşamın kaçınılamaz bir olgusu olarak kabul edilmesi gerektiğini öngören bir inançlar sistemi" (Marshall, 2009: 373) olan kadercilik (fatalizm) ile de yakından ilişkilendirilir. Bunun en başat sebebi ise, kaderciliğin sıklıkla "yoksulluğun, kronik hastalığın ve işsizliğin bir özelliği olarak görülmesi"dir (Marshall, 2009: 373). Bu anlamda Oscar Lewis de, kaderciliğin "yoksulluk kültürü"nün temel özelliklerinden birisi olduğunu savunur (Marshall, 2009: 373).

Söz konusu kapsamda, katlımcılara sahip oldukları yoksulluklarının sebepleri sorulduğunda verilen yanıtların katılımcıların yaş gruplarına göre değişiklik gösterdiği görülmüştür. Bu anlamda orta yaşlı ve yaşı olan katılımcılarda, yoksulluğun kendi kaderleri olduğu ve bu durumun devam edeceği düşüncesinin hâkim olduğu görülmüştür. Buna karşılık, genç katılımcılarda ise, yoksulluğun kendi kaderleri olmadığı, başka sebeplerinin olduğu, bu sebepleri ortadan kaldırmak için de çalışmaları ve mücadele etmeleri gerektiği düşüncesinin hâkim olduğu görülmüş ve bu anlamda umutlu oldukları gözlenmiştir. "Sizce yoksulluk/fakirlik kader midir, yoksa başka sebepleri var mı?" şeklindeki soruya, çavuşluk/elçilik yapan Süleyman ile amelelik/işçilik yapan Ahmet şu yanıtları vermiştir:

“Kaderdir. Şimdi şöyle: Bugün bu işi biz yapmazsak kim yapacak? Şimdi alemlerin rabbi tüm insanları zengin yapsa olmaz. Herkes zengin olsa kim bu işi yapacak? Çark dönmez. Bugün zengin de olacak, fakir de. Herkes olacak ki çark dönsün. Bugün biz kirazları yetiştirmezsek, toplamazsak sen nasıl yiyecektin? Bunlar makineyle toplanıyor mu? Hayır! Ellerle toplanıyor, [ellerini göstererek] bu ellerle toplanıyor. (...) Bugün herkes zengin olsa da olmaz. Kim yapacak bu işi? Olmaz. Allah seni de zengin edebilir beni de. Kadere inancım tamdır. Bu bizim kaderimizdir" (Süleyman, erkek, 45 yaşında, çavuş, görüşme tarihi: 18.07.2020).

"Bizim memleketin toprakları çoktur ama iş yoktur. Urfa bölgesi, Ceylanpınar, Siverek, Hilvan... Ama kimseye fayda vermiyor. Yılda 500 bin insan çıkıyor. Uzak memleketlere çalışmaya gidiyor. Bazıları yollarda kaza ediyor, ölüyor. Bazıları da buralarda ölüyor. Cenazelerini ambulanslara yükleyip gönderiyoruz Urfa'ya. Yani fakirlik Urfalıların kaderidir. Ölüm de onların kaderidir. Yollarda kaza geçirip ölmek de... Geçen kaza oldu, 7-8 kişi öldü. Arap, Kürt, Türk fark etmez. Nihayetinde insanlar ve işçiler. Sonuçta burada her yıl en az 50 kişi uzak memleketlerde ölüyor. İnsanın kendi memleketinde ölmesi ayrı başka memlekette cenazesinin tabuta koyularak götürülmesi ayrıdır. Memleketimiz hala ağaların elinde. Memleketimin toprakları çoktur. Urfa'nın toprağı, Eskişehir, Kırşehir, Konya ve diğer kentlerden daha çoktur. Suyu da barajı da vardır. Ama boşturlar. Çünkü ağaların elindeler. Fakirlere yoksullara bir şey yok!" (Ahmet, erkek, 55 yaşında, görüşme tarihi: 17.07.2020).
Görüldüğü gibi, çavuş olan Süleyman ile işçi olan Ahmet'in bu konudaki yaklaşımı yoksulluğun kendi kaderleri olduğu yönündedir. Ancak diğer taraftan da çocuk ve genç katlımcılar ise yoksulluğun kendi kaderleri olmadığını söylemişlerdir. Örneğin, katılımcılardan 18 yaşındaki Mustafa (erkek, görüşme tarihi: 17.07.2020), "yoksulluk kaderimiz değildir. Olmamalıdır da. Yoksulluk kader değildir" demiştir. Zeynep ve Zehra ise, yoksulluğun kendi kaderleri olmadığını bunun için mücadele etmeleri gerektiğinin altını çizmişlerdir. Zeynep, "umutlarım var, hayallerimi gerçekleştirmek istiyorum. (...) Üniversite sınavına girip eczacılık bölümünü kazanmak istiyorum. Alacağım maaşla da anne ve babama bakacağım" (Zeynep, kadın, 16 yaşında, görüşme tarihi: 17.07.2020) derken, kardeşi Zehra da "her şeye rağmen hayallerimin peşinden koşuyorum. Yani umutlarımı yitirmedim. Okulda çok düşük notlar da alıyorum. Çünkü derslerime odaklanamıyorum ve çalışamıyorum. Ama hayallerimi asla yıkmadım. Eğer ben hayallerimin peşinden gitmezsem hayatim hep böyle devam edecek" (Zehra, kadın, 14 yaşında, görüşme tarihi: 17.07.2020) demiştir.

Bir diğer kavram ve kuram seti ise, "yoksunluk döngüsü (cycle of deprivation)" ya da "yoksulluk kısır döngüsü"dür. Bu kuram, yoksulluğun kuşaklar boyunca aktarılmasını ifade etmek üzere özellikle de 1970'lerde yaygınlaşmıştır. Bu kurama göre, yoksulluğu kuşaktan kuşağa aktaran başat mekanizma "aile patolojisi"dir. Nitekim yoksul evler ve mahallelerde eğitim düzeyinin düşük olması, evlerin içinde bulunduğu kötü hal, kalıcı işsizlik gibi durumlar bu olguyla açıklanabilir (Marshall, 2009: 829). Bu kuramın temel argümanı ise şöyledir: "Yoksunluk ve refah yardımlarına bağımlılık tamamen yoksulların kusuru olmasa bile, kesinlikle ciddi yapısal kökenlere de bağlıdır; bu, birey ve topluluk patolojilerine daha az önem vermekle birlikte, daha önceki yoksulluk kültürü teziyle pek çok ortak yön taşıyan bir yorumdur" (Marshall, 2009: 829).

Ancak yoksulluk kısır döngüsünü yoksulluk kültüründen ayıran temel fark, yoksulluğun bir kültürel kod haline getirilmediği yani bir kültür olarak yaşanmadığı, sadece kişi veya ailelerin içinde bulundukları koşullar gereği çeşitli biçimlerde kuşaktan kuşağa aktarılan ve bu sebeple de bir sarmala (yoksulluk sarmalı) dönüşen durum olduğudur. Kişi kendini bu sarmalın içinde bulduğu ve bunu değiştirebilme imkanını da elde etmesi çok zor olduğu için, sahip olduğu yoksulluk aktarılarak devam etmekte bu anlamda kısır bir döngüye dönüşebilmektedir. Bu duruma aktarıl(an)mış yoksulluk (transmitted deprivation) da denilebilir.

Bu bağlamda mevsimlik gezici tarım işçileri için de bu tür ilişkilerin işlendiği görülmektedir. Katılımcıların çoğunun bir yoksulluk sarmalı içinde yaşadıkları ve bunun bazı katılımcılar için nesilden nesile aktarıldığı gözlemlenmiştir. Örneğin, çavuşluk/ elçilik yapan Hatun, anne ve babasının hatta dedelerinin de bu işlerde çalıştığını ve nihayetinde kendisinin de bu işlerde çalışmak zorunda kaldığını şöyle anlatmaktadır: "Evlenmeden önce de tarım işçisiydim. Annem, babam da öyleydi. Adana'ya Çukurova'ya pamuk toplamaya giderdik. (...) Dedelerim ve [dedemin] dedeleri de tarım işçileriydi. Amelelik yapıyorlardı. Bizim toprağımı yoktu. Yoksa ne işimiz var milletin derdini çekiyoruz?" (Hatun, 43 yaşında, kadın, çavuş, görüşme tarihi: 19.07.2020). 
Bununla birlikte, yoksulluk kısır döngüsü kuramı, yoksulların yoksul oldukları için yoksulluk çektiklerini ifade eder. Yani aslında içinde debelenilen bir çarkın ve sarmalın olduğu anlaşılmaktadır. Bu kısır döngüyü sağlayan şey ise, içinde bulunan ve yaşam şartlarını belirleyen yoksulluk sarmalının kendisidir. Bu anlamıyla, mevsimlik gezici tarım işçiliğinin bu yönünün de bulunduğunun alt çizilmelidir. Nitekim mevsimlik gezici tarım işçiliğinde neredeyse tüm şartlar bu döngünün yeniden üretimi sağlayarak onun bir sarmala dönüşümünü kolaylaştırmakta ve nesilden nesile aktarımı sağlamaktadır. Araştırma kapsamında görüştüğümüz Ahmet'in yaşadıklarını anlattı̆̆ı hikayesi tam da bu durumu özetler niteliktedir:

\section{“(...) O zaman dedim ki, 'ben ne yapabilirim? Ancak gece} gündüz çalışırsam, ancak ev sahibi olabilirim'. Çocuklarım da çok küçüktü. Şehirde inşaat işi vardı. Yani amelelik vardı. Dedim ki, 'arttk kendimi ev sahibi yapacağım'. Gece gündüz çalışmaya başladım. Bir taraftan samanda amelelik diğer taraftan da inşaatta işçi olarak çalışıyordum durmadan. Kalkttk ambar biçiminde bir ev yapttk ve içinde yaşamaya başladık. Bu ambarda 7-8 yıl kaldık. Dedik ki, 'ikinci kat da yapalım'. Kalktık mevsimlik tarım işlerinde çalışmak için Çorum'a gittik. Geldiğimizde ikinci katt yapttk ama yarıda kaldı, çünkü paramız bitti. Sıvasız, boyasız, kapısız kaldı. Bu sefer, evin sıvasını yapmak için bir yıl, boya ve kapılar için bir yıl derken... 10-15 yıl boyunca her yıl Çorum'a çalışmaya gittik. Bu 10-15 yıldan sonra, burayı [Beylikova] bulduk. Burada kendimize yer edindik. 15 yıldır her yıl buraya geliyoruz. Buranın yerlisi olduk. (...) Biz 15 yıldır her yıl alt ay burada kalıyoruz altı ayda memleketimize gidiyoruz. Burada biraz kazandığımız parayı, bu sefer gidip memlekette harcıyoruz. Yılın beşinci ayı olduğunda kalkıp tekrar bu memlekete geliyoruz. Nihayetinde ancak karnımızı doyurabiliyoruz. Yaşamımızı ancak idame ettirebiliyoruz. Bununla ne ölebiliyoruz ne de tam yaşayabiliyoruz. Ölmeyeceğimiz kadar para kazanıyoruz. Bu işin bir serveti yok!" (Ahmet, erkek, 55 yaşında, görüşme tarihi: 17.07.2020).

Yoksulluk tartışmalarında sıklıkla kullanılan bir diğer kavram da yoksulluğun nöbetleşe biçimde yapıldığına ilişkin bir kavram olan "nöbetleşe yoksulluk" kavramıdır. Bu kavram yukarıda tartışılan yoksulluk kültürü ve yoksulluk kısır döngüsünden farklıdır. Bu kavram aslında diğer iki kavramın ters yüz edilmesidir. Nöbetleşe yoksulluk, "kentte göç dalgalarına katılan grupların kendi aralarında kurdukları bir ortaklıktır. Nöbetleşe yoksulluk, esas olarak kente önceden gelmiş göçmen grupları ile kentte imtiyazlı konumda bulunan bazı grupların, kentte daha sonradan gelen kesimler ile diğer imtiyazsız gruplar üzerinden zenginleşmeleri, bir anlamda yoksulluklarını bu gruplara devredebilmeleri sonucunu doğuran bir ilişkiler" (Işık \& Pınarcıoğlu, 2008: 155) ağına gönderme yapar. "Bu anlamda nöbetleşe yoksulluk, toplumun özellikle enformel kesimlerinin kendi aralarında kurdukları ve birbirlerinin üzerinden zenginleşebilmelerini sağlayan eşitsiz güç ilişkileridir" (Işık \& Pınarcıoğlu, 2008: 155-156). Böylelikle, nöbetleşe yoksulluk bir ilişkiler ağ olup, bu ilişkiler ağı "göçmenleri, kentin anonimleştirici etkilerinden korumuş, kentte var kalabilmenin temel koşulu olan iş ve konut piyasasında tutunabilme firsatları yarattğı gibi, göçmenlere tutunabilme ve refahlarını artırabilme" (Işık \& Pınarcıoğlu, 2008: 156) firsatını ve umudunu sağlamıştır.
Bununla birlikte, bir yerde nöbetleşe yoksulluk kuramının işleyebilmesi için, yukarıda değinilen ilişkiler ağının olması şarttır. En önemlisi de, bir yerde nöbetleşe yoksulluk kuramının işlenebilmesi için orada iş imkanlarının olması gerekir. Örneğin bu kuram özellikle de sanayi sektörünün geliştiği kentlerde işlevsel iken, sanayi, ticaret, inşaat ve diğer iş sektörlerinin gelişmediği özellikle de küçük ve orta büyüklükteki kentlerde işlememiştir. Bu anlamda bu kuram mevsimlik gezici tarım işçi aileleri için işleyememiştir (Benek, 2020a; 2020b). Mevsimlik gezici tarım işçiliğinin en fazla olduğu illerden olan Diyarbakır, Şanlıurfa gibi illere daha önce ilçelerden ve köylerden göçle gelen bu insanlar, bu kentlerde sanayi sektörü olmadığı, iş imkanları da kısıtlı olduğu için kendi sınıf ve statülerini yükseltebilecek bir imkana sahip olamadılar. Buna bir de mülksüzlük ve topraksızlığa ek olarak, şehirde yaşamanın zorlukları da eklenince bu insanların aynı işi devam ettirmekten başka çareleri kalmamıştr. Bu sebeple de, yılın belirli aylarında bulundukları illeri terk ederek başka illere mevsimlik gezici tarım işlerinde çalışmaya devam etmektedirler. Araştırma kapsamında görüşülen tüm aileler bu işi çok uzun bir süredir yaptıklarını (bazıları 30-35 yıldan fazla) bazıları da bu işin babalarından ve dedelerinden kendilerine kalan tek miras olduğunu söylemişlerdir. Kısacası, bu kuram söz konusu gerekçelerden dolayı mevsimlik gezici tarım işçileri için işleyememiştir. Katılımcılardan uzun yıllardır mevsimlik gezici tarım işçisi Ahmet'in anlattkları bu anlamda oldukça aydınlatıcıdır:

"Biz, babam ve dedemlerle birlikte yaşıyorduk. Yaklaşık otuz kişi birlikte yaşıyorduk. Hane reisimiz dedemizdi. O zaman traktör filan yoktu. Öküzümüz vardı. Onunla tarlayı sürüyorduk. Koyun, keçi, kuzu ve oğlaklarımız vardı. Bunları otlatiyorduk. Köyde mısır, mercimek ve buğday hasadında çalışıyorduk. Ben henüz çocuktum, bir amcam vardı, askere gitti geldi. Benim dedem üç evlilik yapmışt. Üç kadınla evliydi. Amcam askerden geldiğinde, benim babam da ikinci evlilik yapt, annemin üstüne kuma getirdi. Amcam da askerden geldi. Daha da kalabalıklaşttk. Hane nüfusumuz çok oldu, yaklaşık 30'u geçtik. Kalktık birbirimizden ayrıldık. Annem de köyün sahibine 'biz de bugün ayrılacağız' dedi. Biz de ayrıldık. O zaman henüz 13-14 yaşındaydım, çocuktum. Ben, iki erkek ve bir kız kardeşimle birlikte ayrıldık. Ayrıldık ama, ne yiyebiliriz? Hiçbir şeyimiz yoktu. Kalktık başkalarının işini yapmaya başladık. İlk olarak, milletin buzağılarını otlatmaya başladık. Bir yıl sonra, çobanlık yapmaya başladık. Bir iki yıl da bunu yaptı. Hasat zamanında buğday toplama işinde çalışıyorduk. Bununla geçimizi sağlıyorduk. Bir müddet sonra dayılarımız biraz bizimle ilgilendiler. Babam pek bizimle ilgilenmezdi. Bir iki yıl daha geçtikten sonra biraz büyüdük. Bu sefer kalkttk, birkaç tane koyun aldık, besledik. Bu şekilde geçimimizi yapabiliyorduk. Aradan zaman geçti, memleket yıkıldı, yakıldı. [80'li 90'lı yıllardaki köy boşaltmalarına attf yapıyor]. Kalktık şehre geldik. Urfa'ya geldik. Hiçbir iş de yapamıyorduk şehirde. Köyde tarım ve hayvancılığa alışmıştik. Yine buradan tarlaya kaçttk. Nihayetinde çok çile çektik. Şehirden köye geldik. Tüm evlerimiz yakılmışt, hiçbir şey kalmamışt. Kalktık topraktan bir ev yaptık. Yine tarım işlerine başladık. Ama yavaş yavaş traktör de çıkmaya başladı. Bizim yaptığımız pek çok işi traktör yapmaya başladı. Tarla sürme işi de bizden çıkt, traktör işi olmaya başladı. Yine kalktık şehre göç ettik. Şehirde de bir yıl kirada kaldık. Farelerin içinde gezdiği kötü bir evdi. (...) 
Burada çalışabileceğim bir iş yoktu. Bir mesleğim de yoktu. Bir birikimimiz de olmadığı için, burada da tutunamadık. Kalktık, Çorum'a tarım işlerinde çalışmaya gittik" (Ahmet, erkek, 55 yaşında, görüşme tarihi: 17.07.2020).

Görüldüğü gibi, doğduğundan beridir tarım işlerinde çalıştğını belirten 55 yaşındaki Ahmet'in anlattlğı kendi hayat hikayesi bir taraftan iç göçün sebep ve sonuçlarını bir taraftan Türkiye'deki sosyolojik dönüşüm hakkında oldukça ipucunu sağlarken diğer taraftan da Türkiye'de nöbetleşe yoksulluk kuramının, neden mevsimlik tarım işçileri için işleyemediğini de açıkça göstermektedir.

\section{5. "Siz İnsan Değil Misiniz?": Sosyal Dışlanmanın Bir Boyutu Olarak "Yoksul" Olmak}

“Çalışma ilişkilerinin tamamen enformel olması, işverenlerin işçilerine karşı herhangi bir sorumluluk yüklenmemelerinin yanında, işçilerin yaptıkları iş üzerinden sosyal güvenceye de sahip olmadıklarının göstergesidir. (...) Mevsimlik [gezici] tarım işçilerinin önemli bir kısmı sağlık sigortasından yeşil kart aracılığıyla yararlanırken iş kazası, meslek hastalığı, emeklilik gibi sosyal güvenliğin diğer kollarından faydalanamamaktadırlar" (Çınar, 2014: 34).

Söz konusu sebeplerle mevsimlik gezici tarım işçileri yaşadıkları yerlerde sosyal dışlanmaya maruz kalmaktadır. Nitekim bu yönde yapılan araştırmalar, "işçilerin yaşadıkları sosyal dışlanmanın nedenlerinin etnik kökenleri, düşük vasıflı işçi olmaları, barınma koşullarının kötü olması ve barınma koşullarının bir sonucu olarak çalıştikları yerlerde daha fazla görünür olan yoksullukları" (Çınar, 2014: 36) olduğunu göstermekte$\operatorname{dir}$ (Fotoğraf 4).
Mevsimlik gezici tarım işçileri, kendilerine dönük sosyal dışlanmaların pandemi öncesiyle kıyaslandığında arttı̆ını söylemişlerdir. Hatta "insani onurları" aşağılanacak biçimde dışlanmaya maruz kaldıklarını ifade etmişlerdir. 60 yaşında olup, mevsimlik gezici tarım işlerinde çalışan Muharrem, çocuğu yaşındaki kişilerin kendisine, "ne biçim insanlarsınız?" (Muharrem, erkek, 60 yaşında, görüşme tarihi: 18.07.2020) dediğini söyleyerek şöyle devam etmiştir:

"Bugün benim mülküm olsaydı, bu hastalıkta herkes evindeyken ben ailemle birlikte buraya gelip, bu insanların kahrını, derdini çeker miydim? Buradakiler bize diyorlar ki, 'siz Urfalısınız, siz ...' (...). Diyorum ki, 'be adam! Biz geliyoruz, burda size kölelik yapıyoruz, kölelik!' Diyor ki, 'he valla doğru'. Diyorum ki, 'neden peki bana, bize bunları söylüyorsun?' Diyor ki, 'yahu işte bir defa kaçt ağzımdan'. Halbuki her zaman ağzından kaçırıyor. (...) Vallahi kendi işi için olmazsa, Vallahi bize merhaba demez, Allah'ın selamını da vermez. Kendi işleri için burada olduğumuzu biliyorlar, kendi işleri olmazsa Vallahi bırakmazlar biz çadırlarımızdan yolun başına çıkalım. Kendi işlerinden dolayı mecburdurlar. Diyorlar ki 'gelin!'. Eğer ki, kendi işlerinden değilse, biz işi bitirdiğimizde bize demiyorlar 'gelin bir çay için'. Bir çay bile vermiyorlar. Çünkü işi bitti. İşleri bitiyor" (Muharrem, erkek, 60 yaşında, görüşme tarihi: 18.07.2020).

Görüldüğü gibi, Muharrem yoksulluk başta olmak üzere içinde bulunduğu şartlardan dolayı ağır biçimde sosyal dışlanmaya maruz kalmıştır. Muharrem tarlada çapa yaparken veya tarlayı yabancı otlardan temizlerken, işverenin tarlaya gelip kendilerini "aşağıladığını" söylemiştir. Muharrem tarlada çalışırken yanlışlıkla da olsa bir defa bir tarlada biraz ot bırakılması durumunda bunun işveren tarafindan asla kabul edilemez olduğunu belirtmiştir:

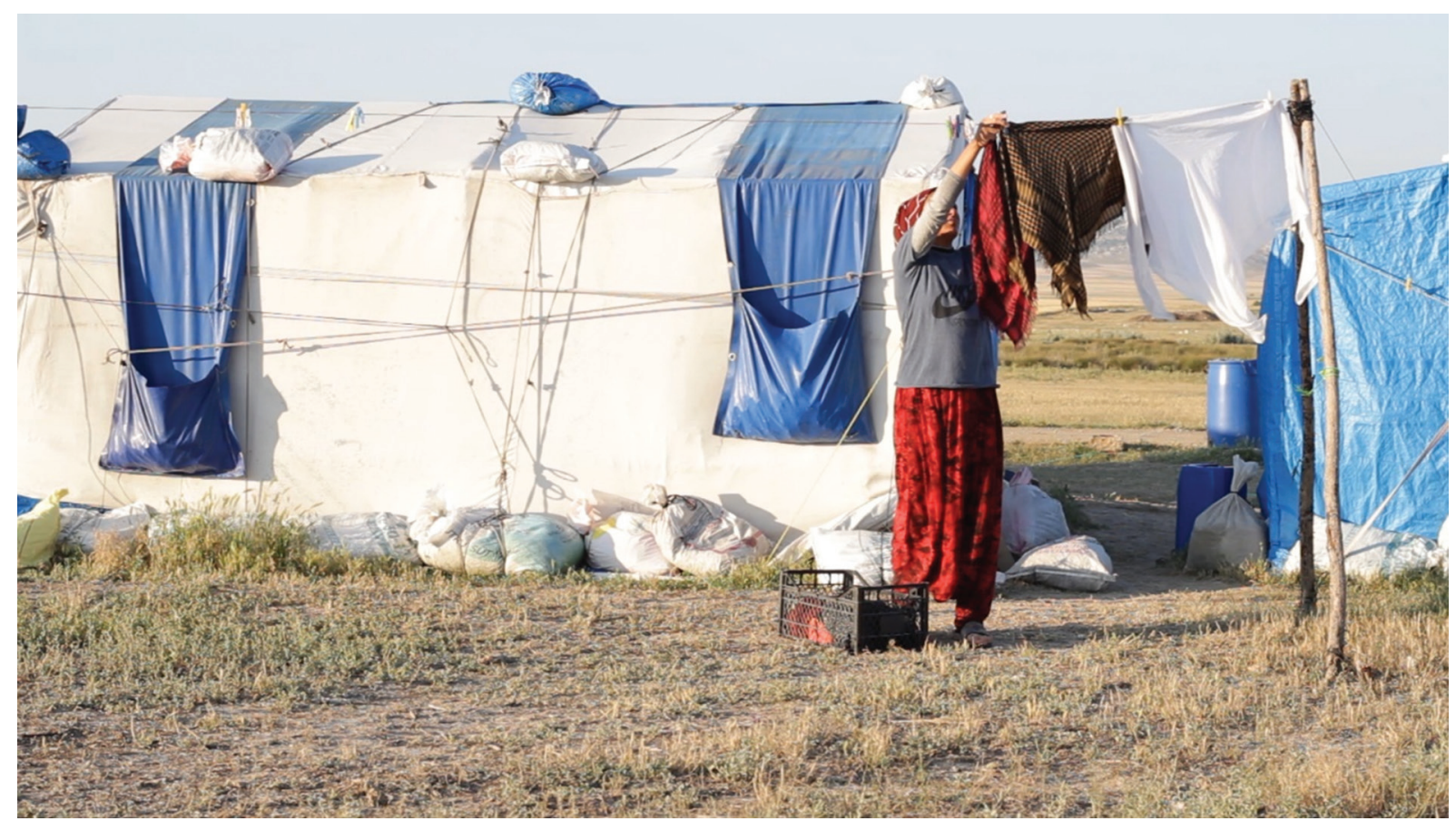

Fotoğraf 4. Beylikova'da bulunan çadırlardaki bir mevsimlik gezici kadın tarım işçisi elle yıkadıkları çamaşırları asıyor

Photo 4. A seasonal agricultural women worker who hanging clothes that her wash by hand in Beylikova

Kaynak: Bilal Çiftçi, Temmuz, 2020.

\footnotetext{
Sosyal dışlanmanın boyutları üzerine yapılmış önemli bir çalışma için bakınız: Naciye Yıldız, Kadın Yoksul ve Kürt: Toplumsal Dışlanmanın Boyutları, NotaBene Yayınları, İstanbul, 2015.
} 
"Biz buraya geliyoruz, milletin köleliğini yapıyoruz. Biz tarlada çalışıyoruz. Adam [işvereni kastediyor] geliyor görüyor, hepimiz çalışıyoruz. Adam geliyor, diyor: 'yahu, siz insan değil misiniz?' diyor. 'Siz insan değilsiniz!' diyor bize. Ben diyorum ki 'yahu biz ne yapmışız?'. Diyor ki, 'işte şurada ot bırakmışsınız.' Yani koskoca bir tarlada bir yerde ya birkaç tane ot kalıyor ya kalmıyor adam bunun için bize hakaret ediyor. 'Siz neden böyle yaptınız yahu' diyor." (Muharrem, erkek, 60 yaşında, görüşme tarihi: 18.07.2020).

Görüldüğü gibi bazı işverenler işçilere "siz insan değil misiniz? Siz insan değilsiniz" gibi onur incitici ve aşağılayıcı cümleler kullanmışlardır. Bununla da yetinmeyerek çoğu zaman yapılan işi beğenmeyip, işçilerin kimlikleri üzerinden "siz ne yaptınız? Uçtunuz mu, içtiniz mi?" gibi farklı cümlelerle dışlama faaliyetlerine devam etmişlerdir:

"Biz akşama kadar çalışıyoruz. Bizim için bir yevmiye de bir yevmiyedir. (...) Akşam olup yanımıza geldiklerinde, diyorlar ki, 'ne çabuk bitirdiniz? siz ne yaptınız? Uçtunuz mu, içtiniz mi?' Demiyorlar, 'Allah sizden razı olsun, işimizi bitirdiniz' Akşama kadar da çalışsak onlar için boş. 'Yarım yevmiyeye çalışıyoruz' dersek, 'yok!' demezler. Hiçbir kıymeti harbiyemiz yok. İşçiyiz sonuçta. (...) Bunlarda insanlık yok!" (Muharrem, erkek, 60 yaşında, görüşme tarihi: 18.07.2020).

Görüldüğü gibi, mevsimlik gezici tarım işçilerinin, mülksüzlük/ topraksızlık halinin önemli bir sonucu olarak "işçi/amele" olmak, yani "yoksul" olmak, gittikleri yerlerde çeşitli kesimlerce sosyal dışlanmalarının önünü açmaktadır. Dolayısıyla "yoksul" olmak burada sosyal dışlanmanın önemli bir boyutu olarak karşımıza çıkmaktadır.

\section{Araştırma Kapsamında Ulaşılan Bazı Önemli Bulgular}

Alan araştırmasında yapılan gözlem ve görüşmelerden hareketle, Covid-19 Pandemisinin mevsimlik gezici tarım işçilerini oldukça olumsuz etkilediği ortaya çıkmışttr. Zaten pandemi öncesi de toplumun oldukça kırılgan bir kesimini oluşturan mevsimlik gezici işçi ailelerinin yaşam ve çalışma koşulları pandemi ile birlikte daha da içinden çıkılmaz bir hal almıştr. Covid-19 ile kendi aralarındaki ilişkiyi ironi yapar biçimde açıklayan Ahmet, aslında bu kesimin ne kadar kırılgan bir grup olduğunu göstermektedir: "Biz nasıl annemizden doğmuşsak, Korona bizi vurmuş [gülüşmeler]. Fakirler için Korona nedir? Zaten bu iş ölümdür. Zaten hepsi yollarda kaza yapıyorlar, ölüyorlar" (Ahmet, erkek, 55 yaşında, görüşme tarihi: 17.07.2020).

Böylesi hassas bir süreçte yüzbinlerce insanların bu işi yapmak zorunda kalma durumu hakkında, "ben şahsen çavuşum, buraya bir yıl gelmezsem, acım. O yüzden bu hastalıkta kalkıp buralara kadar geldik. Sadece ben de değil benim gibi binlerce insan var" (Süleyman, erkek, 45 yaşında, çavuş, görüşme tarihi: 18.07.2020) diyen Süleyman, aslında insanların başka alternatifleri olmadığı ve yapabilecekleri tek iş bu olduğu için, zorunlu olarak bu işi yaptıklarına dikkat çekmiştir.

Mevsimlik gezici tarım işçilerinin bazılarının Covid-19 sürecinde izinli olarak çalışmalarına karşı yaklaşımları iznin bilinçli olarak çıkarıldığıydı. Çünkü onlara göre, yüzbinlerce insan bu işi yapmaktadır ve bu kadar insanın evde kalması durumunda nasıl geçinebilecekleri sorun teşkil edeceğinden böyle bir karar alındı. Aksi durumda yetkililerin bu kadar kişinin geçimini sağlama noktasında sorumlulukları vardı (Mehmet, erkek, 17 yaşında, görüşme tarihi: 17.07.2020). Onlar bu ekonomik krizde bunu göze alamadılar ve böyle bir karar çıkararak bu yükü hafiflettiler: "Virüs vardı ama virüs bize de vardı. Neden bazılarına var bazılarına yok mu bu virüs? Zenginler kaldı, fakirler yollara düştü" (Mehmet, erkek, 17 yaşında, görüşme tarihi: 17.07.2020).

Dahası, katılımcıların ısrarla dikkat çekmek istediği diğer bir önemli nokta ise, Pandemi ile birlikte bu işe aksine daha fazla insanın rağbet etmeye başladığıdır. Bu da alınan ücretlerin ve yevmiyelerin düşmesi başta olmak özere çeşitli olumsuzluklara sebep olduğu yönündedir. İşçiler, daha önce "karın tokluğu"na çalıştıkları bu işte de artık "ekmeğin" kalmadığını söylemişlerdir:

"Bu hastalığın [Covid-19 Pandemisi] ortaya çıkmasıyla bu işte çalışan insan sayısı artt. Daha önce bu işi yapmayanlar da yollara çıktılar. Bu işi yapmaya başladılar. Bu hastalık birçok insanı işsiz bırakt. Insanlar mecbur çalışmak zorunda olduğu için bu işe de yöneldiler. Bir de bu işin devlet tarafindan bir izni de vardı. Diğer işler gibi değildi. Çalışan sayısı ikiye katlandı. Eskiden buraya 100 bin kişi geliyorduysa şimdi 200 bin kişi geliyor. Bu yüzden eskiden alt ayda yaptığımız bir iş şimdi üç ayda bitiyor. Bu işte de bir ekmek kalmadı. Gittikçe koşullar bizim için daha zor oluyor" (Ahmet, erkek, yaş 55, görüşme tarihi: 17.07.2020).

Araştırma kapsamında görüşme yapılanlar, sıklıkla mülksüzlükten, topraksızlıktan bu bağlamda da Toprak Reformu'ndan ${ }^{6}$ bahsetmişlerdir. Bütün bunlara rağmen, başta pandeminin yarattı̆ı olumsuz sonuçlar olmak üzere, buna Suriyelilerin de eklemlenmesiyle kendilerinin işin içinden çıkılmaz bir hale girdiklerini söylemişlerdir:

“Rahmetli Ecevit, Toprak Reformu yapt.. Bize ve ağalara dağıtth toprakları. Ama bizler o tarlaları sürmekten korktuk. Ağalar neticede o toprakları bizden aldılar. El koydular. Burada devletin de bir suçu var. Bu yoksul ve fakir kesim de eğer devlet tarafindan korunsa ve toprak sahibi olabilse, kimse kalkıp kendi memleketinden kalkıp buraya gelip, buradan Edirne'ye kadar Bat illerinde tarlalarda çalışmak için gelmezler. Bu iş de yoksulların kaderidir. Her yıl gelip burada çadırlarımızı kuruyoruz. Burada kaldığımız kadar kendi memleketimizde kalamıyoruz. Burada altı aydan fazla çalışıp bu parayı da alıp Urfa'ya dönüyoruz. Bir mesleğimiz de yok. İş de yok. Suriyelilerin de memleketleri yıkıldı, kaçtlar gelip bize sığındılar.

\footnotetext{
6 "Dar anlamda toprak reformu; topraksız ve az topraklı çiftçiler lehine, toprak mülkiyet hakkının yeniden düzenlenmesi olarak tarif edilmektedir. Tarım reformı ise; tarımsal yapının düzeltilmesi yönünden ele alınabilecek her türlü tedbirleri ifade etmektedir. Bu anlamda, 19.7.1973 yılında Toprak ve Tarım Reformu Kanunu çıkarılmıştır. Aynı yıl yürürlüğe giren bu kanun, sadece Şanlıurfa ilinde uygulanmıştır. Kanunun ilk uygulamasının Şanlıurfa ilinde başlatılmasının nedeni, söz konusu ilde arazi mülkiyetinin dağılımında, dikkat çekici bir adaletsizliğin olmasıdır. Bu bakımdan, Şanlıurfa ilinde yapılan uygulamalar, şu şekildedir:

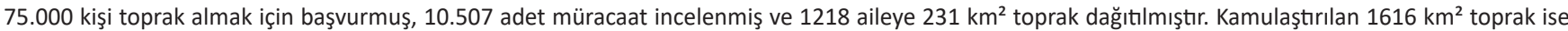
1613 kişiden (aileden) kamulaştırılmıştır. Ancak bu kanun, kısa bir süre sonra, 1977 yılında Anayasa Mahkemesi tarafindan iptal edilmiş ve 10.5 .1978 yılında yürürlükte kaldırılmıştır" (Benek, 2005: 133).
} 
Urfa'nın nüfusu neredeyse ikiye katlandı. Inşaat sektörü bitti. Dükkân açmışlar, dükkanları vergisiz çalışıyor. Vergi vermiyorlar, askerlik yapmıyorlar. Nihayetinde bize yük oldular. Bu yük de bizim vergimizden ve çalışmamızdan gidiyor. Sonuç olarak biz de onlarla birlikte perişan olduk" (Ahmet, erkek, 55 yaşında, görüşme tarihi: 17.07.2020).

Araştırma kapsamında görüşülenlerin yakındığı bir diğer konu "ağalık sistemi" ve bunun bir sonucu olarak gördükleri topraksızlıktır. Çözüm olarak da Toprak Reformu yapılarak "ağalık sisteminin" çökertilmesi gerektiğinin altını çizmişlerdir. Çünkü onlara göre, her yıl yüzbinlerce mevsimlik gezici işçinin yollara düşmesinin sebebi bu topraksızlık halidir. "Bizim memlekette bir ağanın 7 köyü var. Bazı ağalar tanıyorum 30'a yakın köyü var. Bu adalet midir? Devlet bu toprakları herkese dağıtsa memleketimizde fakir kalmaz. Bunun için toprak reformu şart" (Ahmet, erkek, 55 yaşında, görüşme tarihi: 17.07.2020) diyen Ahmet, mevsimlik gezici tarım işçilerinin bu durumdan kurtulabilmesinin tek yolunun bu olduğunun altını çizmiştir.

Genellikle çok çocuklu olan bu aileler, çocuk işçiliği yasak olmasına rağmen, eğitim çağındaki çocuklarını da yevmiye karşılığında tarım işlerinde işçi olarak çalıştırmaktadırlar. "Şimdi çok pişmanım. Bilseydim, 9 çocuk yapmazdım. Getirmezdim dünyaya. Getirdik de ne yaptık, millete köle yaptık. Köle olarak çalışıyorlar. Günahlarını aldık hepsinin" (Ayşe, kadın, 50 yaşında, görüşme tarihi: 17.07.2020) diyen Ayşe, çok çocuklu olmanın pişmanlığını yaşadığını söylemiştir. Çünkü bu çocukların geçimlerinin sağlanabilmesi için kendilerinin de bu işte çalışmak zorunda kaldıklarını bu yüzden de çoğunun okulunu bırakmak zorunda kaldığını söylemiştir. Sekizi kadın biri erkek 9 çocuk annesi olan mevsimlik gezici tarım işçisi Ayşe'nin çaIışma ve yaşam koşulları içerisinde bu çocuklarını nasıl yetiştirdiğine ilişkin anlatthkları, mevsimlik gezici tarım işçilerinin hem yaşam koşulları hem de çalışma koşulları ve çocuk yetiştirebilme durumlarını ortaya koyar niteliktedir:

"Sabah kahvaltılarını hazırlamak için erkenden uyanıyordum. Kahvalt yapıldıktan sonra direkt işe gidiyorduk. Öğle de gelip çadırda yemek hazırlayıp götürüyordum. Bir taraftan da çalışıyorduk tabi. Akşam olunca hepimiz birlikte çadıra gelirdik. Bu sefer akşam yemeği ve çadırın toparlanması... Ben yemek hazırlayana kadar, çocuklarımın bazıları çok yorgun oldukları için aç yatıyorlardı" (Ayşe, kadın, 50 yaşında, görüşme tarihi: 17.07.2020).

"Çocuklarım hepsi küçüktü, pamuk toplamaya gidiyorlardı. Ben de onlarla birlikte gidiyordum. Öğle çadıra gelip çocukların yemeklerini hazırlayıp götürüyordum. Üç tane çocuğum ise çok küçüktü ve çalışamıyorlardı. Bir tanesi bebekti, beşikteydi. Diğer ikisi de 2, 3 yaşlarındaydılar. Diğer çocuklarım da işlerin peşinde koşturuyorlardı. (...) Bu şekilde ömrüm geçti. Çocuklarımın beşiklerini alıp tarlalara götürüyordum. Beşikler ve çocuklar ağaçların gölgesindeyken ben milletin işini yapıyordum. Yılan vardı, fare vardı... Bu çocuklar ben gelene kadar sahipsiz kalıyorlardı. Ben de çalıştı̆ım için işimi terk edemiyordum, çocuklarıma gitmek için. Her defasında beşiklerini başka bir tarlaya götürüyordum. Bu şekilde çocuklarımı büyüttüm. Çorum'da bir tarlada çalışırken, çocuklarımın biri beşikteyken diğer ikisini de battaniyeye sarıp bir ağacın altında gölgede bırakmıştım.
Oradaki yerlilerden biri geldi, dedi ki, 'bu sabah yüreğime ateş düştü yenge'. Dedim ki, 'ne olmuş?'. Dedi ki, 'size o kadar günahım geldi, o kadar günahım geldi ki. Çocuklarının birini beşiğe koymuşsun, diğer ikisini de battaniyeye sarıp yere koymuşsun. Yazık size, siz nasıl yaşıyorsunuz? Size çok günahım geldi. Daha sabahtır, soğuktur. Bu çocukları bir yılan ısırsa... İçime ateş düştü, gözüme yaşlar girdi"' (Ayşe, kadın, 50 yaşında, görüşme tarihi: 17.07.2020).

Araştırma kapsamında ulaşılan bir diğer önemli bulgu ise, mesai saatlerinin çok uzun olması ve kadınların, kız çocuklarının erkeklerden çok daha fazla çalıştıklarının ortaya çıkmasıdır. Iş̧̧iler sabah saat 7'den akşam saat 7'ye kadar çalıştıklarını söylemişlerdir. Böylelikle işçilerin 12 saat çalıştıkları ortaya çıkmıştır. Ayrıca kadınların ve kız çocuklarının iki mesai yaptı̆̆ anlaşılmıştır. Nitekim kadınlar ve kız çocukları, sabah işe gitmeden iki saat önce (sabah saat 5'te) uyandıklarını ve tarlaya gitmek için ön hazırlık yaptıklarını, çadırlarının içini toparladıklarını, diğerlerini uyandırdıklarını ve kahvaltı hazırladıklarını söylemişlerdir. Aynı şekilde, akşam işleri bitip çadırlarına geldiklerinde ise, bu sefer akşam yemeğini hazırladıklarını, yarına hazırlık yaptıklarını, bulaşıkları yıkadıklarını, çocukları uyuttuklarını yani 3-4 saat daha çalışttklarını söylemişlerdir. Böylelikle, kadınların bir günde 15-16 saat çalıştıkları ortaya çıkmıştır.

Araştırma kapsamında ulaşılan bir başka önemli bulgu da çaIışma yaşı ile ilgilidir. Nitekim, çalışma yaşının 11-12'lere kadar düştüğü görülmüştür. Araştırma kapsamında görüşülen 15 kişiden 5'i 18 yaşından küçüktür ve "çocuk işçi”dir (Zehra, Zeynep, Mehmet, Eyyüp, Kıymet). Bu çocuk işçiler bir taraftan okumaya çalışmakta diğer taraftan da ailelerine yardım etmek amacıyla mevsimlik gezici tarım işlerinde çalışmaktadırlar. Mevsimlik gezici tarım işçisi ailelerinin çocuklarının önemli bir çoğunluğu da çalışmak zorunda kaldıkları için eğitimlerine devam edememektedir. Örneğin bizim görüştüğümüz, İbrahim (22 yaşında) ortaokulu bitirdikten sonra okula devam edemediğini söylerken, Ramazan (18 yaşında) da lise öğrencisiyken okulu terk etmek zorunda kaldığını söylemiştir.

Bu şartlar altında okuyabilen çocuklar da her yıl okuldan 2 ay erken ayrılmak, 2 ay da geç başlamak zorunda kalmaktadırlar. $\mathrm{Bu}$ da onların hem eğitim hayatlarını hem de eğitim hayatlarındaki başarılarını olumsuz etkilemektedir (Fotoğraf 5). 16 yaşındaki çocuk işçi Zeynep, "ben lise bire gidiyorum. Her yıl okuldan erken ayrılıyoruz. Bu yıl da erken ayrıldık. Her yıl 6-7 ay gelip burada çalışıyorum. Hem iş̧̧iyim hem öğrenci" (Zeynep, kadın, 16 yaşında, görüşme tarihi: 17.07.2020) derken, kardeşi 14 yaşındaki çocuk işçi Zehra ise, "okuldan iki ay erken ayrılıp iki ay geç başlıyorum. iki ay geç başladığım için derslerden çok geri kalıyorum. Bu psikolojik olarak beni etkiliyor. Mesela ilk sınavlardan kötü not alıyorum hep. Bu yüzden ikinci sınavlara daha çok çalışmam gerekiyor" (Zehra, kadın, 14 yaşında, görüşme tarihi: 17.07.2020) diyerek bu durumun onun üzerinde yarattı̆ı psiko-sosyal etkilere atıf yaparken aynı zamanda "üç yıldır üst üste okulu yarıda bırakıp buraya geldiğim için şu an sekizinci sınıftayım ve şu an çok daha fazla zorlanıyorum. Çünkü eğitimim hep kesik kesik geçti. Çok fazla zorlandığım için ve eksiklerim de çok olduğu için bu sene Liselere Giriş Sınavı'na giremedim" (Zehra, kadın, 14 yaşında, görüşme tarihi: 17.07.2020) diyerek şartların kendisini nasıl mağdur ettiğini ifade etmiştir. 


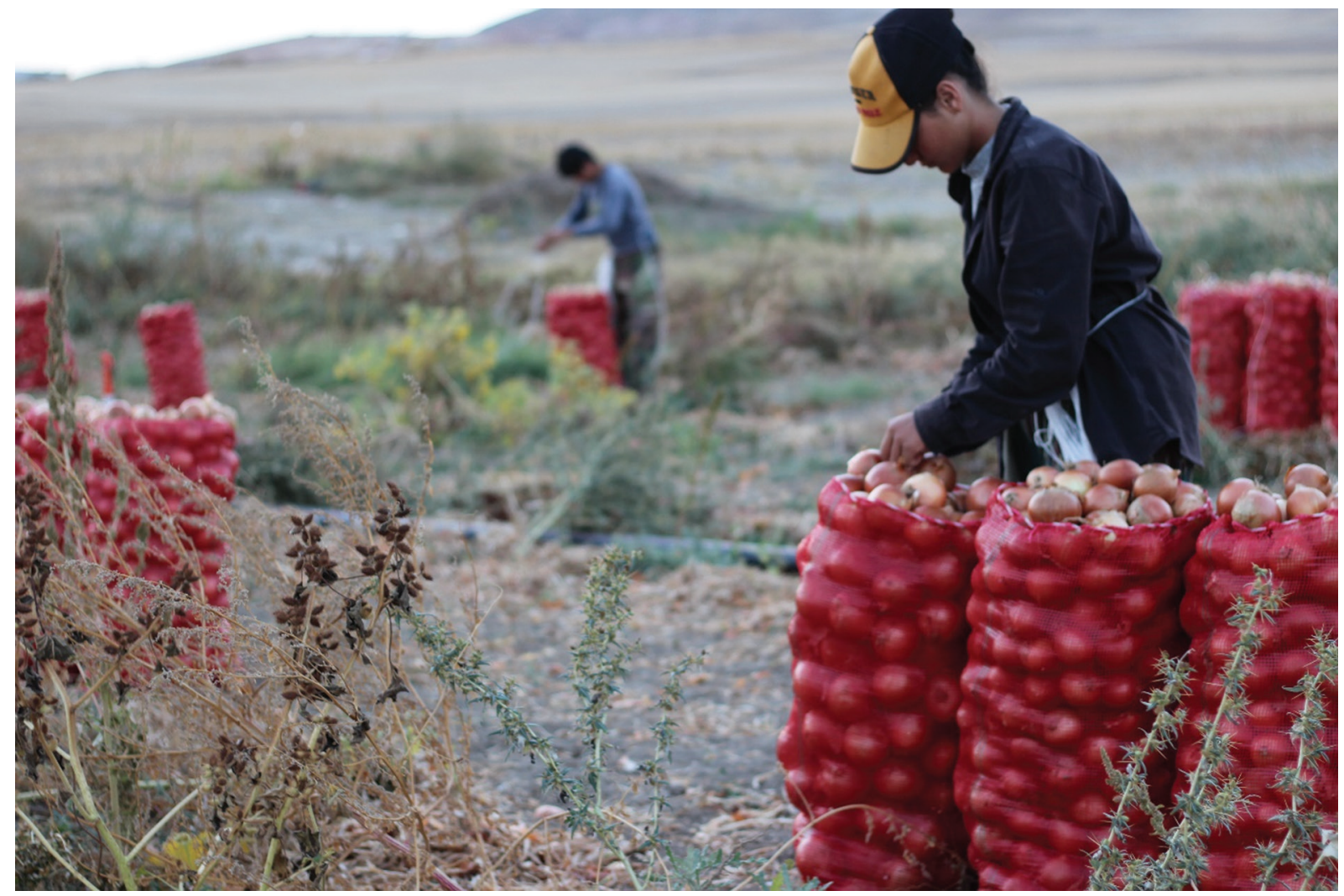

Fotoğraf 5. Beylikova'da mevsimlik gezici tarım işlerinde çalışan eğitim çağındaki çocuklar

Photo 5. Children of school age working in seasonal agricultural work in Beylikova

Kaynak: Bilal Çiftçi, Temmuz, 2020.

Mevsimlik gezici tarım işçiliğinin yaşam ve çalışma koşullarının çocukları ve işçi çocukları olumsuz yönde etkilediğine dair izlenimler de olmuştur. Adeta toplumun "kangreni" haline gelmiş ve bir sarmala dönüşen mevsimlik gezici tarım işçiliğinin bir döngü halinde sürekli devam etmesi bu ailelerin çocuklarını pek çok anlamda olumsuz etkilemektedir. Örneğin, bu araşttrmanın mottosunda da verildiği gibi 11 yaşından beridir mevsimlik gezici tarım işçisi olarak çalışan Zehra, "Biz bayramımızı hiç Urfa'da geçirmedik. Hep burada geçirdik. O yüzden Urfa'da bayram nasıl oluyor bilmiyorum. (...) Yazı da hiç Urfa'da geçirmedik. O yüzden Urfa'da yaz nasıl geçiyor pek bilmiyorum. Çok sıcak diyorlar. (...) Her bayram kendime söylüyorum: 'keşke bu bayram Urfa'da olsam'. Diyorum ki 'gelecek sene bu bayramda Urfa'da olacağım'. Öyle umut ediyorum hep. Küçüklüğümden beridir hep bunu hayal ettim. Ama şimdiye kadar hiçbir bayramda Urfa'da kalamadım. Hep başka şehirlerde ve çadırlarda bayramı geçirdim" (Zehra, kadın, 14 yaşında, görüşme tarihi: 17.07.2020) demiştir.

Bununla birlikte, çıkarılan yasa gereği, pandemi sürecinde işçilerin yol ücretinin işveren tarafindan ödenmesi gerekirken, işçiler "çıkış ili"nden "varış" iline giderken yol masraflarını tümüyle kendileri karşıladığını söylemişlerdir. Bu süreçte, bir aile için yaklaşık 2000-2500 TL civarı yol masrafi çıktığı söylenmiştir (Süleyman, erkek, 45 yaşında, çavuş, görüşme tarihi: 18.07.2020). Bu durumun da insanları mağdur ettiği sıklıkla dillendirilmiştir. Ayrıca, yasa gereği, "çıkış ili"nden "varış" iline giderken bir araca çok sayıda insanın binmemesi ve sınırlı sayıda insanın binmesi istenmiştir. Bu da yolcu sayısı azaltıldığından yol masraflarının ikiye üçe katlamasına sebep olmuştur. Bu durum aileleri ekonomik olarak zor duruma düşürmüştür.
Pek çok kişi yol masrafinı karşılayabilmek için tanıdık ve akrabalarından borç aldıklarını söylemişlerdir. Bununla birlikte, ailelerin ekonomik gücü yetmediğinden pek çok ailenin bu kurala uyamadığı ve uymadığı için de ayrıca yolda ceza aldığı ve o cezaları ödemek için de ikinci bir defa borç altına girdikleri ortaya çıkmıştır:

“Insanlar mağdur oldu. 20 kişilik dolmuşa 7 kişi bindi bu yıl. Bu da yol masraflarını ikiye üçe katladı. Üstelik yolda yakalandık ve bize ceza yazıldı. Dedim ki, 'biz Urfa'dan geliyoruz, mevsimlik işçileriz. 7 kişi ile bir arabada 1000 km yol gelemeyiz. Kuvvetimiz yok'. Dinlemediler. En son içimizden sekiz kişiye ceza yazıldı. Bu sorunu işveren ve devlet kendi aralarında çözmeleri gerekiyordu, ama çözemediler. İşçi kendi yol masraflarını kendisi ödemek zorunda kaldı neticede" (Süleyman, erkek, 45 yaşında, çavuş, görüşme tarihi: 18.07.2020).

Bir diğer önemli konu ise, çalışanların aldığı ücretin düşüklügüdür. Çoğu kez herhangi bir pazarlık dahi yapılmadan yapılan işlerde yevmiyelerin genelde günlük 75-90 TL arasında değiştiği söylenmiştir. Ancak pandemi ile birlikte ödenen ücretlerin düşürülmesi yoluna gidildiği görülmüştür. İşçilere çavuşluk yapan Süleyman, "yevmiyeler 75 TL ile 90 TL arasında değişiyor. Ama bu hastalıktan dolayı her yer kapandığı için herkes bu işe yöneldi ve bu yüzden de yevmiyeler çok düştü. Geçen sene 150-170 kişiyi getiriyordum buraya bu sene 250'den fazla kişiyi getirdim. İşçi sayısı iki kat oldu. İstemediğimiz bazı kişiler bile geldi. Yevmiyeler düştü" (Süleyman, erkek, 45 yaşında, çavuş, görüşme tarihi: 18.07.2020) diyerek, işçilere ödenen ücretin düşüklüğüne vurgu yapmıştır. 
Katılımcılar, pandemi sürecinde Beylikova'ya geldiklerinde karşılaştıkları ilk sorunlardan biri de 15 gün süreyle kendilerinden bulundukları çadırlardan çıkmamalarının istenmesidir. Bu durumun hem kendilerini sağlık açısından riske ettiğini hem de ekonomik olarak olumsuz etkilediğini belirtmişlerdir: "Buraya ilk geldiğimizde bize dediler ki, 15 gün boyunca çadırınızdan çıkmayın, çadırınızda oturun. Biz zaten bir çadırda 10 kişiyiz. Virüs olsa burda da olur. Bu kadar süre boyunca biz çalışamadık, dünya kadar masrafımız oldu. Hepsi cebimizden gitti. Bu da zararımızdı. Mademki, bizi buraya getirdin, bıraksaydın çalışsaydık" (Mustafa, erkek, 18 yaşında, görüşme tarihi: 17.07.2020).

Bununla birlikte, pandemi süreci olmasına ve bu konuyla ilgili çıkarılan genelgede de belirtilmesine rağmen, mevsimlik gezici tarım işçi ailelerine ait çadırların olduğu yerlerde, suyun, sabunun ve dezenfektanın bulunmadığı gözlemlenmiştir. İşçilerin bunlara erişimi kısıtlıdır. İşçiler, içme suyunu dahi yakın civarda bulunan bir köyden getirdiklerini söylemişlerdir. İşçiler, suya erişimde zorlandıklarını, uzak yerlerden sırtlarına alarak getirdikleri bazı suların tuzlu olması sebebiyle kimi işçilerin hastanelik olduğu da belirtmişlerdir. Ayrıca (çıkarılan genelge gereği, olması gerekirken), çadır alanlarında elektrik, internet, tuvalet ve banyo olmadığı (çıkarılan genelge gereği olmaması gerekirken), çadırların birbirlerine çok yakın olduğu, bir çadırda 7-8 kişinin kaldığı (bazı çadırlarda 10 kişi) da ortaya çıkmıştır. Çadır alanlarında suyun ve elektriğin olmaması sebebiyle, mevsimlik gezici tarım işçilerinin ve çocuklarının yeterince banyo yapamadıkları çünkü içmek için zor su bulabildikleri anlaşılmıştır. Işçiler yemeklerini ateşte pişirmekte, banyo yapacakları suyu dahi ateşte ısıtmaktadırlar (Fotoğraf 6).

\section{Sonuç}

Kuşkusuz ki, tarım sektörü en güvencesiz ve öngörülemeyen sektörlerden biridir. Covid-19 salgını bu gerçeği daha da belirgin hale getirmiştir (Bochtis vd., 2020: 3). Nitekim Covid-19 sürecinde neredeyse bütün dünya ülkeleri sınırlarını kapatmıştır. Fakat gıda tedarik zinciri söz konusu olunca, ne yazık ki göçmen işçiler bu sınırlamadan muaf tutulmuştur. Örneğin bu süreçte, ABD Meksika'dan, Almanya Romanya'dan, Polonya da Ukrayna'dan tarım işlerinde çalıştırılmak üzere göçmen işçi getirtmiştir. İlginç biçimde, Türkiye'de bulunan Suriyeliler sadece bulundukları şehirlerde çalışabildikleri halde bu süreçte mevsimlik işçi olarak il dışına gitmelerine izin verilmiştir (Benek, 2020b).

Öteden beri, görünmeyen veya çalışma koşulları ve genel durumları çok da tartışma konusu yapılmayan mevsimlik gezici tarım işçileri ile çocuk işçilerin, Covid-19 Pandemisi ile birlikte yaşam ve çalışma koşulları gittikçe daha da kötü hale gelmeye başlamıştır. Genelde mevsimlik tarım işçiliği özelde de çocuk işçiliği bu toplumun "kanayan yarası" ve "adeta kangreni" haline gelmiş bulunmaktadır. Pandemi sürecinde eve kapanma ve sokağa çıkma yasakları devam ederken bu kısıtlamalar "tarımsal üretimi gerçekleştirdikleri" gerekçesiyle (İçişleri Bakanlığı, sayı: 89780865-153.E.6202) mevsimlik tarım işçilerini, ne yazık ki kapsayamamaktadır. Benek'in (2020a; 2020b) de dikkat çektiği gibi, mevsimlik tarım işçi aileleri ve bu sektörde çalışan çocuk işçiler, adeta virüs ile baş başa bırakılarak/kalarak kaderlerine terkedilmektedir. Bu yüzden onları zorlayan şey aslında virüs değil, içinde bulundukları koşullardır. Nitekim Kalkınma Atölyesi'nin de dikkat çektiği gibi, pandemi sürecinde yoksulluk ile virüs arasında (Development Workshop, 2020) kalan bir gruptan

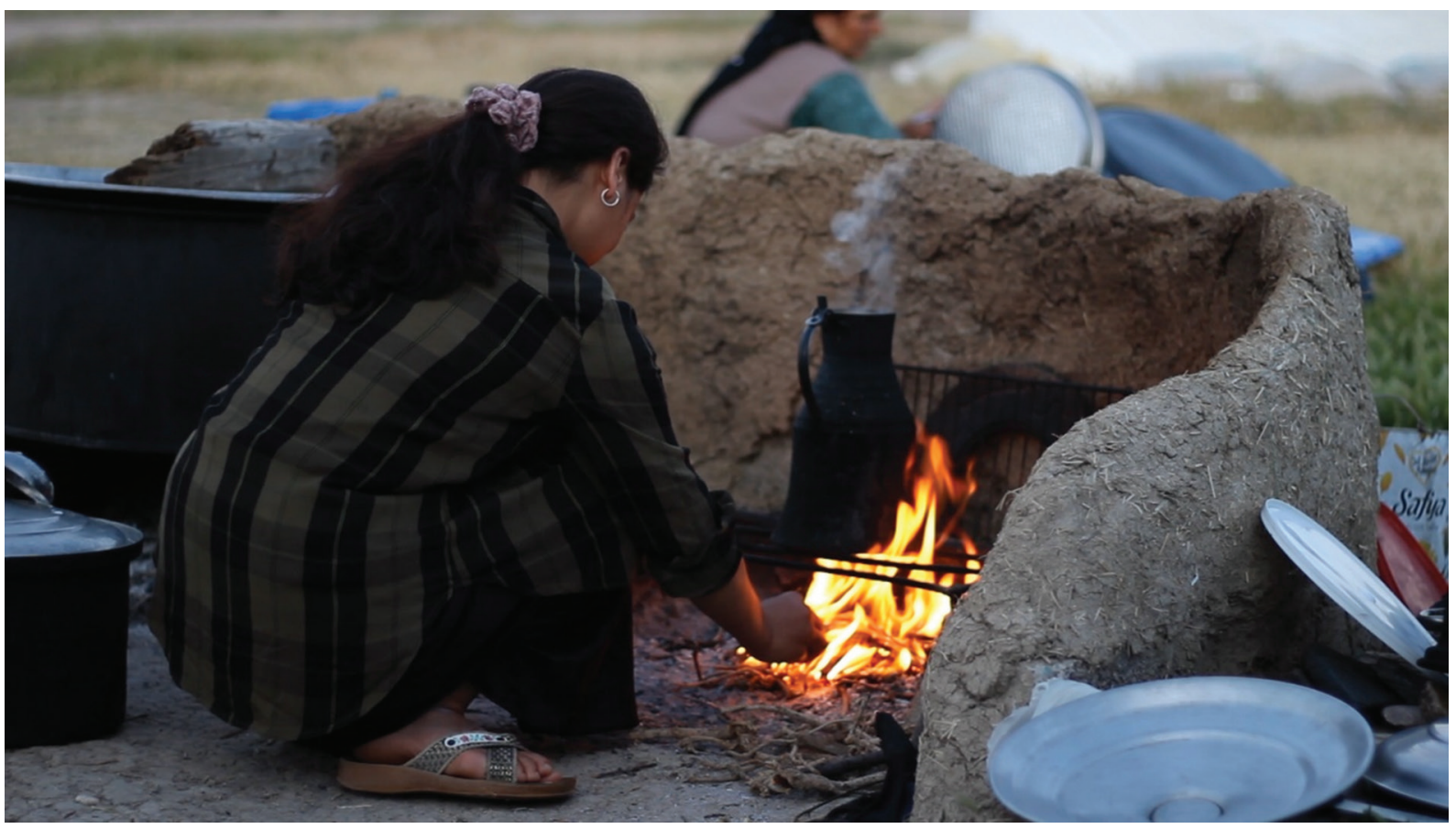

Fotoğraf 6. Beylikova'da bulunan çadırlardaki bir mevsimlik gezici kadın tarım işçisi ateşin başında

Photo 6. A seasonal agricultural women worker who in tents in Beylikova standing by the fire Kaynak: Bilal Çiftçi, Temmuz, 2020. 
bahsediyoruz. Bir yoksulluk kısır döngüsü halini alan mevsimlik gezici tarım işçisi aileler, bir "yoksulluk sarmalı" içinde olduklarını ve bu "sarmalın" onları hangi koşullarda olursa olsun çalışmaya zorladığını söylemişlerdir.

Netice itibariyle bu inceleme, pandemi sürecinde mevsimlik gezici tarım işçilerinin ulaşım masraflarının ikiye katlandığını; çadırlarda kalan kişi sayısının azaltıımasından dolayı alınması gereken çadır sayısının artırıldığını; bu süreçte Covid-19’a karşı sağlıklı ateş ölçümünün olmadığını, yapılanların da sembolik olarak kaldığını tespit etmiştir. Ayrıca, inceleme, çalışma yaşının 10-12 yaşına kadar indiğini; işçilerin günlük 11-12 saat ve düşük yevmiyeyle ve sigortasız çalıştıklarını; bir çadırda yaklaşık 6-7 kişinin kaldığını, temiz suya ve sabuna erişimde zorlandıklarını ortaya koymuştur. Dahası bu çalışma, kadınların erkeklere oranla çok daha fazla çalıştıklarını, kadınların bir taraftan tarla işleri diğer taraftan da çadırdaki temizlik ve yemek işlerini yapmak zorunda kaldıkları için iki mesai yaptıklarını, böylelikle, kadın ve kız çocuklarının neredeyse günün 15 saatini çalışarak geçirdiğini; mevsimlik gezici tarım işçilerinin, başta işverenler olmak üzere, gittikleri yerlerde çeşitli kesimlerce "insani onurları" "aşağılanacak" düzeyde sosyal dışlanmaya maruz kaldıklarını saptamıştır.

Mevsimlik tarım işçilerinin sahip oldukları "kötü yaşam koşulları"na pandemi şartlarının da eklemlenmesiyle daha da kötü bir hal aldığı gözlemlenmiştir. Ayrıca, mevsimlik gezici tarım işçilerinin gittikleri bölgelerde, çok uzun süre güneşe maruz kaldıkları, sıtma, tansiyon, kalp hastalıkları ve tarımsal alanda yoğun ilaç, gübre kullanımı sonucu çeşitli hastalıklara yakalandıkları, temiz suya erişemedikleri, bu yüzden içtikleri su yüzünden birçok kişinin hastanelik olduğu da çarpıcı biçimde ortaya çıkmıştır.

Covid-19 Pandemi sürecinde mevsimlik gezici tarım işçilerinin çalışma izinleri ve çalışma koşullarının oluşturulması vs. ile ilgili yasaların çıkarılması, sosyal devlet anlayışı içerisinde onları koruyan, haklarını koruma altına alan yasaların da çıkarılabileceği anlamına gelir. Bu sebeple, sosyal devlet anlayışı içerisinde gerekli yasaların çıkarılması önem arz etmektedir. Bununla birlikte sahada görüştüğümüz işçiler, yöreden yöreye çalışma şartları ve kendilerine ödenen ücretin farklılık gösterdiğini aynı işi yapmalarına rağmen bazı yerlerde çok az ücret aldıklarını dile getirmişlerdir. Bu anlamda, işçilere ödenen ücret ve işçilerin çalışma saatleri ve koşulları yöreden yöreye veya bölgeden bölgeye farklılık göstermemeli veya bu farklılık en aza indirgenmelidir (Benek, 2020a; 2020b). Bunun için de devlet otoritesinin gerekli girişimde bulunması gerekmektedir.

Diğer bir önemli nokta ise mevsimlik tarım işçiliğinin kurumsallaşması ve bu sektöre yasal düzenlemenin getirilmesidir. Sosyal devlet anlayışı çerçevesinde mevsimlik tarım işçilerinin hem yaşam koşulları hem de çalışma koşulları düzenlenmelidir. Sadece düzenlemek de yetmez, bunu denetleyen etkin bir mekanizmanın da olması şarttır. Çünkü, mevsimlik gezici tarım işçileri Türkiye'nin en yoksul ve en kırılgan kesimleri arasındadır. Örneğin, sahada görüşülen bütün işçiler, sigortasız çalıştırıldıklarını söylemişlerdir. Bu anlamda, bu işçilerin sigortaları yapılmalıdır. Bunu da devlet ve işveren kendi arasında yapmalıdır. Çalışma saatleri ve alınan ücretin bir standarda bağlanması gerekmektedir.

Bununla birlikte işçilerin sıklıkla dile getirdiği bir başka konu ise, maruz kaldıkları sosyal dışlanmadır. Söz konusu dışlanmaların altında yatan sebepler, etnik kökenleri, geldikleri il ve bölge, sosyo-ekonomik yapıları, içinde bulundukları kötü yaşam koşulları ve benzeridir. Bu dışlanmaların önünü kesmenin en temel yolu, dışlanma sebeplerini ortadan kaldırmaktır. Mesela, mevsimlik gezici tarım işçilerinin hakları yasalarla koruma altına alınmalıdır. Çalışma koşuları iyileştirilmelidir. Çocuk işçiliğinin son bulması şarttır. Eğitime erişemeyen çocukların eğitime erişimleri için gerekli girişimlerde bulunulmalıdır.

\section{Etik Kurul İzni}

HARRAN ÜNIVERSITESI Sosyal ve Beşeri Bilimler Etik Kurulu'nun 11.11.2020 tarihli, E.45299 sayılı ve 2020/97 numaralı kurul kararı.

\section{Kaynaklar}

Akalın, M. (2018). Mevsimlik tarım iş̧̧ilerinin barınma koşullarının değerlendirilmesi: Yenice, Tarsus, Silifke örnekleri. Sosyal Güvence Dergisi, 7(13), 1-30.

Altın, C. (2014). Mevsimlik göç ve yoksulluk: Ankara-Polatlı mevsimlik tarım işçileri örneği [Yayınlanmamış yüksek lisans tezi]. Süleyman Demirel Üniversitesi Sosyal Bilimler Enstitüsü.

Anonim. (17 Nisan 2020). Seyahat izni almak için akın ettiler! bir haftada 17 bin kişi. Hürriyet. https://www.hurriyet.com. tr/gundem/seyahat-izni-almak-icin-akin-ettiler-bir-haftada-17-bin-kisi-41496093

Anonim. (4 Eylül 2020). Sakarya'da Kürt işçiler saldırıya uğradı. Evrensel. https://www.evrensel.net/haber/413269/sakaryada-kurt-isciler-saldiriya-ugradi

Arslan, A. (2018). Mevsimlik tarım iş̧̧isi kadınların kentsel mekânda ve tarladaki gündelik yaşam deneyimleri: Şanlıurfa örneğinde bir inceleme [Yayınlanmamış yüksek lisans tezi]. İnönü Üniversitesi Sosyal Bilimler Enstitüsü.

Aslan, K. (2020). Kayısı tarımında mevsimlik tarım işçiliği ve insana yakışır iş olanakları açısından durum analizi: Malatya ili araştırması [Yayınlanmamış yüksek lisans tezi]. Ankara Üniversitesi Fen Bilimleri Enstitüsü.

Ata, R. (2020). Gezici mevsimlik tarım işçileri ve sosyal hizmet ihtiyacı: Adıyaman il örneği [Yayınlanmamış yüksek lisans tezi]. Üsküdar Üniversitesi Sağlık Bilimleri Enstitüsü.

Atı̧, M. (2019). Mevsimlik iş̧̧ilerde sosyal dışlanmışlık: Adıyaman ili örneği [Yayınlanmamış doktora tezi]. Adıyaman Üniversitesi Sosyal Bilimler Enstitüsü.

Baş, B. (2019). Türkiye'de tarımsal dönüşüm ve mevsimlik tarım işçiliği: Adana örneği [Yayınlanmamış yüksek lisans tezi]. Marmara Üniversitesi Sosyal Bilimler Enstitüsü. 
Benek, S. (2005). Coğrafi planlama yönünden Şanlıurfa ilinin tarımsal yapısı [Yayınlanmamış doktora tezi]. Ankara Üniversitesi Sosyal Bilimler Enstitüsü.

Benek, S. (2006). Şanlıurfa ilinin tarımsal yapısı, sorunları ve çözüm önerileri. Coğrafi Bilimler Dergisi, 4(1), 67-91.

Benek, S. (2009). Ortaya çıkışı, gelişme seyri ve bölgeye etkileri bakımından Güneydoğu Anadolu Projesi (GAP). Ankara Üniversitesi SBF Dergisi, 64(3), 45-71.

Benek, S. (2020a). Coronavirüs en çok mevsimlik işçileri etkiledi. 25 Haziran 2020, K24, https://www.kurdistan24.net/tr/ news/63741ea1-4bfc-4750-bdbd-b448be93b985

Benek, S. (2020b). Pandemi mevsimlik tarım işçisi aileleri nasıl etkiledi? 5 Haziran 2020, Bianet; https://m.bianet.org/bianet/ tarim/225201-pandemi-mevsimlik-tarim-iscisi-aileleri-nasil-etkiledi

Benek, S., \& Ökten, Ş. (2011). Mevsimlik tarım işçilerinin yaşam koşullarına ilişkin bir araştırma: Hilvan ilçesi (Şanlıurfa) örneği. Gaziantep Üniversitesi Sosyal Bilimler Dergisi, 10(2), 653 676.

Bochtis, D., Benos, L., Lampridi, M., Marinoudi, V., Pearson, S. \& Sørensen, C.G. (2020). Agricultural workforce crisis in light of the Covid-19 Pandemic. Sustainability, 12(19), https://doi. org/10.3390/su12198212

Bulut, E. (2013). Mevsimlik tarım işçilerinin yaşam ve çalışma koşullarına ilişkin bir saha araştırması: Kocaali örneği [Yayınlanmamış yüksek lisans tezi]. Sakarya Üniversitesi Sosyal Bilimler Enstitüsü.

Cortignani, R., Carulli, G. \& Dono, G. (2020). Covid-19 and labour in agriculture: economic and productive impacts in an agricultural area of the Mediterranean. Italian Journal of Agronomy, 15(1653), 172-181. Doi:10.4081/ija.2020.1653

Çakmak, G. (2018). Mevsimlik tarım işçilerinin yaşam ve çalışma koşullarının sosyal dışlanma bağlamında bir araştırması: Çanakkale ili örneği [Yayınlanmamış yüksek lisans tezi]. Çanakkale Onsekiz Mart Üniversitesi Sosyal Bilimler Enstitüsü.

Çarıkçı, E. E. (2016). Critique of vulnerability discourse through an alternative development approach: a case of seasonal migrant agricultural workers in Turkey [Yayınlanmamış doktora tezi]. Orta Doğu Teknik Üniversitesi Sosyal Bilimler Enstitüsü.

Çayır, A. K. (2020). Mevsimlik tarım işçiliğinde kadın ve çalışma koşulları: Çanakkale-Biga örneği [Yayınlanmamış yüksek lisans tezi]. Trakya Üniversitesi Sosyal Bilimler Enstitüsü.

Çınar, S. (2012). Bağımlı çalışma ilişkileri kapsamında mevsimlik tarım işçilerinin Malatya örneği üzerinden analizi [Yayınlanmamış doktora tezi]. Marmara Üniversitesi Eğitim Bilimleri Enstitüsü.

Çınar, S. (2014). Öteki proletarya: De-proletarizasyon ve mevsimlik tarım iş̧ileri. NotaBene Yayınları.

Çınar, S. \& K. Lordoğlu, (2011). Mevsimlik tarım işçileri: marabadan ücretli findık iş̧̧iliğine. Sosyal Haklar Uluslararası Sempozyumu. Kocaeli Üniversitesi. Kocaeli.

Development Workshop. (2016a). The report on the present situation of foreign migrant workers in seasonal agricultural production in Turkey: Poverty, rivalry and antagonism. http:// www.ka.org.tr/dosyalar/file/Yayinlar/Raporlar/\%C4\%BONG\%C4\%BOL\%C4\%B0ZCE/02/POVERTY\%20RIVALYR\%20AND\%20 ANTAGONISM.pdf
Development Workshop. (2016b). Foreign migrant workers in seasonal agricultural production in Turkey: Policy recommendations. http://www.ka.org.tr/dosyalar/file/Yayinlar/Raporlar/\%C4\%BONG\%C4\%BOL\%C4\%BOZCE/02/POLICY\%20RECOMMENDATIONS.pdf

Development Workshop. (2016c). Employment of migrant workers in agricultural production-lessons learned rights or numbers? (Europe: United Kingdom, Italy, Spain, France, PIcum). http:// www.ka.org.tr/dosyalar/file/Yayinlar/Raporlar/\%C4\%BONG\%C4\%BOL\%C4\%BOZCE/02/LESSONS\%2OLEARNED\%2ORIGHTS\%200R\%20NUMBERS.pdf

Development Workshop. (2018). Circular on seasonal agricultural workers. http://www.ka.org.tr/dosyalar/file/Yayinlar/Raporlar/\%C4\%BONG\%C4\%BOL\%C4\%BOZCE/0606/genelgeEN\%20 kurtulus.pdf

Development Workshop. (2020). Virus or poverty? Impact of coronavirus outbreak on seasonal migrant agricultural workers and their children and on crop farming. http://www.ka.org.tr/ dosyalar/file/virus\%20or\%20poverty.pdf

Erkan. R. (2010). Kentleşme ve sosyal değişme (3.baskı). Bilimadamı Yayınları.

FAO. (2020, April). Migrant workers and the Covid-19 pandemic. http://www.fao.org/3/ca8559en/CA8559EN.pdf

Gira, A. (2017). Siverek (Şanlıurfa) ilçesinde mevsimlik tarımsal iş gücü göçü ve sorunları [Yayınlanmamış yüksek lisans tezi]. Yüzüncü Yıl Üniversitesi Sosyal Bilimler Enstitüsü.

Harvey, D. (2020, 24 Mart). Korona günlerinde anti-kapitalist siyaset: Covid-19 adlı sınıf depremi. (Çeviren: Gencer Çakır). Gazeteduvar. https://www.gazeteduvar.com.tr/dunya-forum/ 2020/03/24/korona-gunlerinde-anti-kapitalist-siyaset-covid-19-adli-sinif-depremi

ILO. (2020a). ILO gözlem 2nci Baskı: Covid-19 ve çalışma yaşamı. 7 Nisan 2020. https://www.ilo.org/wcmsp5/groups/public/--europe/---ro-geneva/---ilo-ankara/documents/briefingnote/ wcms_741784.pdf

ILO. (2020b). Covid-19 ve çalışma yaşamı: etkiler ve yanıtlar. 18 Mart 2020; https://www.ilo.org/wcmsp5/groups/public/--europe/---ro-geneva/---ilo-ankara/documents/briefingnote/ wcms_740193.pdf

ILO. (2020c). Seasonal migrant workers' schemes: rethinking fundamental principles and mechanisms in light of covid-19. https:// www.ilo.org/wcmsp5/groups/public/---ed_protect/---protrav/---migrant/documents/publication/wcms_745481.pdf

IOM. (2020). Covid-19: Policies and impact on seasonal agricultural workers. https://www.iom.int/sites/default/files/documents/seasonal_agricultural_workers_27052020_0.pdf

Işık, O. \& Pınarcıoğlu, M. M. (2008). Nöbetleşe yoksulluk: Sultanbeyli örneği (6.baskı). iletişim Yayınları.

Kamer, H. (2020). Koronavirüs: Mevsimlik tarım işçileri için ne tür düzenlemeler getirildi?. 7 Nisan 2020. BBC; https://www.bbc. com/turkce/haberler-turkiye-52196967

Kılınç, B. (2018). Neredeyse hiçbir mevsimlik tarım işçisi meslek hastası tanımı alamıyor. 16 Ekim 2018. Sivilsayfalar. https:// www.sivilsayfalar.org/2018/10/16/neredeyse-hicbir-mevsimlik-tarim-iscisi-meslek-hastasi-tanimi-alamiyor/\#: :text=Mevsimlik\%20tar\%C4\%B1 m\%20i\%C5\%9F\%C3\%A7isi(MT\%C4\%B0)\%3B,gezici\%20olarak\%20mevsimlik\%20 \%C3\%A7al\%C4\%B1\%C5\%9Fan\%20ki\%C5\%9Fidir 
Marshall. G. (2009). Sosyoloji Sözlüğüü (1. bs). Bilim ve Sanat Yayınları.

Nazik, M. H. (1993). Kadınların mevsimlik tarım işlerinde çalışmalarının ailenin ekonomik durumu ve yaşam biçimine etkisi [Yayınlanmamış doktora tezi]. Ankara Üniversitesi Fen Bilimleri Enstitüsü.

Nuh, H. (2019). Mevsimlik tarım işçilerinin Türk yazılı basınında sunumu [Yayınlanmamış yüksek lisans tezi]. Anadolu Üniversitesi Sosyal Bilimler Enstitüsü.

Öz, C. S. \& Bulut, E. (2013). Mevsimlik tarım işçilerinin türk hukuk sistemi içerisindeki yeri. ÇSGB Çalışma Dünyası Dergisi, 1(1), 94-111.

Özdoğan, F. (2010). Yoksulluk kültürü yaklaşımı üzerine bir değerlendirme. Yardım ve Dayanışma Dergisi, 1(1), 97-114.

Pelek, D. (2011). Hem tarım işçisi, hem kadın, hem Kürt. 13 Ağustos 2011. Evrensel; https://www.evrensel.net/haber/11753/hemtarim-iscisi-hem-kadin-hem-kurt

Sevinç, M. R. (2015). Adana ilinde mevsimlik tarım işçiliğinin sosyo-ekonomik yapısı ve geleceği [Yayınlanmamış doktora tezi]. Çukurova Üniversitesi Fen Bilimleri Enstitüsü.

Şimşek, G. (2020). Fındık tarımında mevsimlik işçilerin çalışma ve yaşam koşulları: Giresun örneği [Yayınlanmamış yüksek lisans tezi] Ordu Üniversitesi Sosyal Bilimler Enstitüsü.

T.C. İçişleri Bakanlığı, İller İdaresi Genel Müdürlüğü, (2020), Koronavirüs Tedbirleri /Mevsimlik Tarım Iş̧̧ileri Genelgesi. Sayı: 89780865-153.E.6202.
Tabcu, G. (2015). Mevsimlik tarım işçilerinin ortaokul çağındaki çocuklarının eğitim sorunlarının sosyolojik olarak incelenmesi [Yayınlanmamış yüksek lisans tezi]. Adıyaman Üniversitesi Sosyal Bilimler Enstitüsü.

Türkiye İstatistik Kurumu (TUiK). (2019). Tarım alanı (dekar). https:// cip.tuik.gov.tr/\#

WTO. (2020). Covid-19 and agriculture: a story of resilience. https:// www.wto.org/english/tratop_e/covid19_e/agric_report_e.pdf

Yavuz, M. (2019). Mevsimlik tarım iş̧̧isi çocukların eğitimde yaşadıkları sorunlara yönelik okul yöneticilerinin ve öğretmenlerin görüşleri: Şanlıurfa ili örneği [Yayınlanmamış yüksek lisans tezi]. Marmara Üniversitesi Eğitim Bilimleri Enstitüsü.

Yıldııım, A. E. (2020). Mevsimlik tarım işçileri için yeni önlemler. 3 Nisan 2020. Tarım Dünyası. https://www.tarimdunyasi. net/2020/04/03/mevsimlik-tarim-iscileri-icin-yeni-onlemler/

Yıldız, N. (2015). Kadın yoksul ve Kürt: Toplumsal dışlanmanın boyutları (1. bs). NotaBene Yayınları.

Yiğit, B. (2018). Gezici mevsimlik tarım işçileri ile yerel mevsimlik tarım işçilerinin durumlarının karşılaştırmalı analizi: Isparta ili örneği [Yayınlanmamış yüksek lisans tezi]. Süleyman Demirel Üniversitesi Sosyal Bilimler Enstitüsü. 